$\begin{array}{lllllllll}\mathbf{A} & \mathbf{R} & \mathbf{T} & \mathbf{Y} & \mathbf{K} & \mathbf{U} & \mathbf{L} & \mathbf{Y}\end{array}$

Collectanea Theologica 89(2019) nr 2

MARCIN MAJEWSKI, KRAKÓW

ORCID: 0000-0002-4362-4812

\title{
ZWIERZĘTA CZYSTE I NIECZYSTE W STARYM TESTAMENCIE. PORZACDEK STWORZENIA JAKO KRYTERIUM PODZIAŁU
}

Odżywianie się - oprócz funkcji biologicznej - spełnia ważne funkcje symboliczne. Zastosowanie czynności jedzenia poza jej podstawowym znaczeniem pokarmowym jest charakterystyczne dla każdej kultury; spożywanie posiłku jest sytuacją społeczną, obrazem wspólnoty, ikoną życia zbiorowego. Posiłek niesie duży ładunek struktury symbolicznej, innej dla każdej cywilizacji. Także w religiach odżywianie się traktowane jest jako nieneutralny, symboliczny i duchowy element systemu wierzeń. Posty, zakazy i nakazy żywnościowe, liturgie jako uczty, religijna symbolika potraw - każda religia jest przepojona strukturami, które wykorzystują czynność i potrzebę fizjologiczną jedzenia i picia do celów metafizycznych.

W tym artykule podejmujemy pytanie, jaką symboliczną informację niesie biblijny podział zwierząt na c z y s te, a więc jadalne, i n i e czyste, a więc niejadalne. Jest to trzeci artykuł z serii. W pierwszym na temat zwierząt nieczystych w Biblii zająłem się omówieniem prawodawstwa z tego zakresu obecnego zwłaszcza w Kpł 11 i Pwt 14. ${ }^{1} \mathrm{~W}$ drugim przedstawiłem i przeanalizowałem dotychczasowe interpretacje egzegetów dotyczące takiego, a nie innego podziału zwierząt. ${ }^{2}$ Ponieważ okazały się dla mnie niesatysfak-

1 M. M a j e w s k i, Zwierzęta czyste i nieczyste w Starym Testamencie, cz. I: Omówienie prawa czystości zwierząt, Zeszyty Naukowe Stowarzyszenia Biblistów Polskich 11/2014, s. 375-398.

2 Te n ż e, Zwierzęta czyste i nieczyste w Starym Testamencie, cz. II: Dotychczasowe interpretacje i ich ocena, Collectanea Theologica 85 (2015) nr 1, s. 5-50. 
cjonujące, w tej części zaproponuję własną hipotezę i przedstawię jej uzasadnienie.

Chodzi o podstawowe pytanie, jakie stawiają czytelnicy prawa pokarmowego Biblii: ${ }^{3}$ Dlaczego Bóg wykluczył pewne gatunki mięsa z diety Izraela? Dlaczego świnia, wielbłąd, osioł, żółw, węgorz, „owoce morza" i wiele innych zwierząt uległo stygmatyzacji i całkowitemu wyeliminowaniu z jadłospisu? Dlaczego akurat te, a nie inne gatunki? Innymi słowy, jakie jest źródło i co rządzi kaszrutem pokarmowym ludu Starego Testamentu oraz wielu współczesnych ludzi? Przecież prawem pokarmowym Biblii kierują się do dziś nie tylko ortodoksyjni Żydzi, ale także niektóre wspólnoty protestanckie, adwentyści oraz wielu ludzi wywodzących zasady życiowe z Pisma Świętego.

Poszukując zasady podziału, skupię się - z trzech powodów zwłaszcza na kapłańskiej wersji prawodawstwa (Kpł 11,1-47). Po pierwsze, panuje coraz powszechniejsza zgoda, że Kpł 11 jest starszą, pierwotną wersją prawa pokarmowego. ${ }^{4}$ To ona ze względu na swój

3 Prawo o nieczystości zwierząt zamiennie określam jako „,prawo pokarmowe”, gdyż są to w istocie reguły pokarmowe „właściwego” odżywiania się. Przepisy żywieniowe sprowadzają się do regulacji nt. zwierząt (ich mięsa, tłuszczu i krwi). Ani rośliny, ani napoje, ani wyroby przetworzone nie podlegają w biblijnym prawodawstwie stałym wykluczeniom czy tabuizacjom.

4 Wspominałem w pierwszej części serii, że w kwestii stosunku chronologicznego Kpł 11 do Pwt 14 klasyczna hipoteza źródeł Pięcioksięgu umieszcza Pwt jako źródło wcześniejsze, w związku z czym egzegeci automatycznie uznają tekst D za starszy. Jednak ci badacze, którzy podjęli analizę porównawczą obu zbiorków prawnych (Noordtzij, Kaiser, Rendtorff, Milgrom, Douglas i kilku innych), wskazują, że wcześniejsza jest wersja Kpł 11. Mary Douglas, która przez całe życie naukowe powracała do studiów prawa pokarmowego Biblii, uznaje P za starsze, przedwygnaniowe źródło, ,ponieważ jedność i spójność Pięcioksięgu w kwestiach dotyczących czystości potwierdzają ten pogląd”; zob. M. D o u g l a s, Ukryte znaczenia. Wybrane szkice antropologiczne, tłum. E. Klekot, Wydawnictwo Marek Drewiecki, Kęty 2007, s. 395, przyp. 7. Egzegeci podnoszą inne argumenty, jak to, że: 1) Kpł wymienia rządzącą prawem zasadę specyfikującą, podczas gdy Pwt 14 wylicza przykłady; 2) Kpł 11 wskazuje cztery jadalne gatunki owadów, podczas gdy Pwt czyni jedynie ogólną wzmiankę itd. Zebraną argumentację zob. np. w J. M i 1 g ro m, Leviticus 1-16, A New Translation with Introduction and 
niezależny charakter stanowiła najprawdopodobniej podstawę zależnego od niej, później zredagowanego i dodanego do D opracowania w Pwt 14,3-21. Niektórzy egzegeci twierdzą, że obie wersje są opracowaniem źródła P. Po drugie, stanowi zwarte, niefragmentaryczne i bardziej kompletne opracowanie tematu, dzięki czemu łatwiej będzie uchwycić idee nim rządzące. Po trzecie, źródłem kapłańskim (P) zajmuję się od wielu lat i chciałbym także tutaj zastosować kreacyjny klucz interpretacyjny - z normatywnymi tekstami uniwersalnymi Rdz 1; Rdz 6-9 oraz Rdz 17 - które dobrze sprawdzają się w interpretacji innych tekstów narracyjnych i prawniczych tej tradycji biblijnej. ${ }^{5}$

Poprzedni artykuł tej serii poświęciłem krytycznym omówieniu dotychczasowych hipotez i zakończyłem go stwierdzeniem: „Wykluczenia są produktem ubocznym, pochodną określonej wizji świata i to ta wizja, a w niej zwierzęta czyste powinny znaleźć się w centrum rozważań. Bo jeśli coś uważane jest za budzące odrazę, wstrętne i nieczyste ze względu na swe anomalie czy odstępstwo od normy, to

Commentary, The Anchor Bible, t. 3, Doubleday, New York 1991 s. 698-704 z konkluzją na s. 704: „D miał cały tekst masorecki Kpł 11 przed sobą, gdy tworzył swoją wersję, modelując ją według własnego kierunku ideologicznego i stylu”. Podobnie konkluduje Rolf Rendtorff: „W obecnej swej formie prawo Pwt 14 wydaje się być zależne od Kpł 11. Rozbieżności należy zawsze rozumieć jako skróty i streszczenia prawa zawartego w Kpł 11"; R. R e n d t o r ff, Die Gesetze in der Priesterschrift. Eine gattungsgeschichtliche Untersuchung, Vandenhoeck \& Ruprecht, Göttingen 1954, s. 45. Nawet więc, gdy uznajemy D za materiał starszy niż P, w tym przypadku Pwt 14 robi wyraźne wrażenie późniejszego wtrętu do D, późniejszego i zależnego opracowania prawa pokamowego.

5 M. M aj e w s k i, Mieszkanie Chwały. Teologia sanktuarium Izraela na pustyni (Wj 25-31 i 35-40), Wydawnictwo Naukowe PAT, Kraków 2008; t e n ż e, W strone Ziemi Obiecanej. Komentarz do Księgi Wyjścia, Wydawnictwo eSPe, Kraków 2011; t e n ż e, Nieczystość śmierci w Torze. Śmierć jako arcytabu, w: A. K u c z, P. M a t u s i a k (red.), Śmierć w antycznej kulturze śródziemnomorskiej, Wydawnictwo Uniwersytetu Śląskiego, Katowice 2015, s. 31-63; t e n ż e, ,Stańcie się wy również świętymi na wzór Świętego, który was powołat”. Świętość Boga a świętość człowieka, w: K. P o r o s ło (red.), ,,Wola Boga jest wasze uświęcenie”. Teologia sakramentów uświęcenia, Wydawnictwo Benedyktynów, Tyniec 2016, s. 61-86; t e n ż e, Pięcioksiag odczytany na nowo. Przesłanie autora kapłańskiego (P) i jego wpływ na powstanie Pięcioksięgu, Wydawnictwo Naukowe UPJP II, Kraków 2018. 
musi istnieć jakaś koncepcja normalności i kategorii, w których owo nieczyste się nie mieści. Idea nieczystości pociąga za sobą istnienie struktury idealnej; leży za nią przekonanie, że istnieje ustalony porządek rzeczy i stojący za nim system wartości, który został pogwałcony. Według mnie jest nim biblijna teologia stworzenia i zawarte w niej reguły wszechświata". W tym artykule przedstawię tę koncepcję szerzej i uzasadnię ją.

\section{Teologia stworzenia jako paradygmat warstwy kapłańskiej}

Warstwa ${ }^{6}$ kapłańska (P) Pięcioksięgu jest efektem pracy lewickiej szkoły teologicznej Izraela rozpoczętej w czasie wygnania babilońskiego i zakończonej w okresie powygnaniowym (V w. przed Chr.). ${ }^{7}$ Szkołę tę stanowiła grupa wykształconych Izraelitów o legalistycznym podejściu do religii, blisko związanych ze świątynią, będących pod wyraźnym wpływem literatury i kultury mezopotamskiej. Gromadziła ona materiały starsze, przedwygnaniowe (wśród których znajduje się prawo pokarmowe) oraz młodsze, wygnaniowe

6 W badaniach Pięcioksięgu kilkukrotnemu przedefiniowaniu uległo rozumienie jego źródeł. Początkowo mówiono o „dokumentach” i traktowano je jako gotowe gotowe dzieła literackie. Później zaczęto częściej mówić o „źródłach”, „szkołach” czy „tradycjach”, przenosząc akcent z pojedynczych autorów na grupy. Dziś tendencja jest odwrotna; rezygnuje się z mówienia o tradycjach, gdyż te wiążą się z obrzędowością i istnieniem przekazów ustnych. Raczej preferuje się najbezpieczniejsze określenie „warstwa”, gdyż termin ten jest na tyle ogólny, że nie akcentuje pierwotnego kształtu opowiadań ani formy przekazu, wskazując jedynie na pochodzenie.

7 Tradycyjnie za Reussem, jego uczniem Grafem i Wellhausenem, przyjmuje się datę wygnaniową lub krótko powygnianiową źródła P (VI-V w.). Część uczonych przywraca źródło P do epoki przedwygnaniowej. Takie stanowsko wyrażają np. R.E. Friedman, R. Abba, J.M. Granitz czy J. Stackert, a zwłaszcza szkoła żydowska badań Pięcioksięgu: Y. Kaufmann, a za nim M. Greenberg, M. Haran, J. Milgrom, U. Cassuto, Y. Grintz, L.I. Rabinowitz, A. Rofé, M. Weinfeld, A. Hurvitz, Z. Zevit, E.A. Spenser, M. Paran, I. Knohl i inni. Z tej grupy uczonych aktywnych na arenie międzynarodowej datę powygnaniową źródła utrzymuje tylko B.A. Levine; zob. szerzej M. M aj e w s k i, Mieszkanie Chwaty, s. 105-114. 
i powygnaniowe, wypracowując przez twórczą pracę i autorską redakcję własną syntezę teologiczną historii świata i Izraela. Kierowała się jasno określonym - choć dla nas wcale nie oczywistym - systemem ideologicznym w (re)konstrukcji dziejów, praw i instytucji ludu JHWH. W tekstach narracyjnych i prawniczych Pięcioksięgu wyróżnia się ona tematyką kultową, sformalizowanym stylem i specyficznym słownictwem, ale przede wszystkim sprecyzowaną w kręgach kapłańskich doktryną prawno-teologiczną, której ważnym elementem jest przekonanie, że doskonały, a więc zgodny z planem Bożym, świat musi opierać się na regułach wpisanych w kapłański poemat o stworzeniu świata $(\operatorname{Rdz} 1){ }^{8}$

Otwierający Biblię tekst o stworzeniu ( $\mathrm{Rdz} 1)$ należy do podstawowej warstwy źródła $\mathrm{P}^{9}$ i jest jego utworem programowym. Zauważa to wielu badaczy. To on wyznacza zasady rządzące światem zgodnie z wolą Bożą, jest wzorem dla prawodawstwa, kultu i życia codziennego. Tylko świat ułożony według aczasowych reguł stworzenia jest światem odbijającym wolę Bożą, światem, który realizuje przykazanie naśladowania Boga (imitatio dei) i czynienia

8 W celu uproszczenia używam oznaczenia Rdz 1, choć poemat stwórczy zahacza również o początek drugiego rozdziału (do 2,3 lub 2,4a).

9 Egzegeza wypracowała podział źródła kapłańskiego na dwie warstwy tradycyjnie oznaczane jako $\mathrm{P}^{\mathrm{G}}$ (Grundschrift - podstawowe pismo kapłańskie) i $\mathrm{P}^{\mathrm{S}}$ (Supplement - kapłańska redakcja); zob. szerzej J. K u s c h k e, Die Lagevorstellung der priesterschriftlichen Erzählung, Zeitschrift für die Alttestamentliche Wissenschaft 63/1951, s. 87n. Nowsze hipotezy wskazują, że kapłańska redakcja $\left(\mathrm{P}^{\mathrm{S}}\right)$ należy do szkoły świętości $(\mathrm{H})$. Dzielą więc kapłański materiał Pięcioksięgu na $\mathrm{P}, \mathrm{H}$ i ewentualnie postkapłańskie dodatki (gł. w Księdze Liczb). Szerzej I. K n o h 1, The Sanctuary of Silence. The Priestly Torah and the Holiness School, tłum. J. F e ld m a n, P. R o d m a n, Fortress Press, Minneapolis 1995; S. S h e c t m a n, J.S. B a d e n (red.), The Strata of the Priestly Writings. Contemporary Debate and Future Directions, ATANT 95, Theologischer Verlag, Zurich 2009; J. S t a c k e r t, Political Allegory in the Priestly Source. The Destruction of Jerusalem, the Exile and their Alternatives, w: P. D u bov s k y, D. M a r k 1, J.-P. S o n n e t (red.), The Fall of Jerusalem and the Rise of the Torah, Mohr Siebeck, Tübingen 2016, s. 211-226. 
wszystkiego na „Jego obraz i Jego podobieństwo”. ${ }^{10}$ Co więcej, powrót do świata idealnego, in illo tempore gwarantuje poprawność kultu i ortodoksję prawa. Tak jest również w przypadku prawa pokarmowego. Życie Izraela, zwłaszcza kultyczne, musi odbijać harmonię, reguły i aksjomaty ustalone w pierwszym tygodniu istnienia świata, tygodniu stwarzania, inaczej bowiem nie jest godne obcowania ze świętością JHWH. Rdz 1 to swego rodzaju mit założycielski źródła kapłańskiego Pięcioksięgu. To święta opowieść, która przez uporządkowaną narrację, powtarzalność formuł i przemyślaną strukturę przekazuje więcej niż treść samych słów i zdań. Wyraża specyficznie rozumiany porządek świata, jaki został ustalony „na początku” przez Boga. Utwór ten wyznacza zasadnicze zręby teologii kapłańskiej. Jest wyrazem kapłańskiego pojmowania Boga, człowieka w świecie, świętości, sanktuarium i szabatu. Jest sensu stricto teologią, czyli nauką o Bogu, antropologią, czyli nauką o człowieku, i kosmologią, czyli nauką o porządku świata. ${ }^{11}$

Niewola babilońska sprzyjała, a poniekąd nawet zmuszała Izraelitów do przemyślenia na nowo podstaw własnej religijności. Jeśli życie religijne ludu JHWH miało być ułożone po niewoli na nowo, oparte na sprawdzonych i ponadczasowych Bożych zasadach, to dla szkoły kapłańskiej nie było pewniejszego miejsca na identyfikację owych zasad, niż powrót do tego, co było „na początku”. Szkoła kapłańska w obliczu niepewności historii odnalazła pewność Bożej woli w analizie mitu kreacyjnego i stwórczej działalności Boga. Oczywiście nie jest tak, że zależność między prawem a mitem w P jest jednokierunkowa, a Rdz 1 jest jednowektorowym źródłem wyobrażeń o liturgicznym stanie idealnym. Istnieje bowiem silne sprzężenie

10 Paradygmat naśladowania Boga (imitatio Dei) i bycia Jego obrazem (imago $\mathrm{Dei}$ ) pojawia się w wielu tekstach źródła kapłańskiego, np. ,Stworzył Bóg człowieka na swój obraz, na obraz Boży go stworzył” (Rdz 1,27; też 1,26); „Bo człowiek został stworzony na obraz Boga” (Rdz 9,6); „Bądźcie świętymi, bo Ja jestem święty, Pan, Bóg wasz!” (Kpł 19,2; 20,7.8.26; 21,6.8.15.23; 22,9.16.32); „Postawisz przybytek według wzoru, który ci ukazałem na górze" (Wj 26,30; zob. Wj 25,40; 27,8) itd. Ideałem staje się naśladowanie wzorca niebiańskiego, stwórczego.

11 Szerzej M. M aj e w s k i, Pięcioksag odczytany na nowo, s. 107-158. 
zwrotne kształtujące teologię kreacyjnego supermitu w relacji do kapłańskiego prawodawstwa. Istnieje wzajemna zależność Rdz 1 i tekstów prawnych P. Kapłański opis dzieła stwórczego (Rdz 1) nie został pomyślany ze względu na samo dzieło, ale włączony w bieg dziejów prowadzących od przymierza z Noem aż po budowę przybytku JHWH i inaugurację kultu.

I tak, już genealogia potomków Adama z Rdz 5 - pierwszy tekst kapłański po opowiadaniu o stworzeniu - przywołuje narrację o „obrazie i podobieństwie” człowieka do Boga i jego stworzeniu „jako mężczyzny i kobiety” (zob. w. 1-2), sama zaś stanowi kontynuację dzieła stworzenia ludzkości i realizację błogosławieństwa płodności. Kolejne opowiadanie, mit o potopie z Rdz 6-9, właśnie w tradycji kapłańskiej zyskuje rangę odnowienia dzieła stworzenia. Sama powódź funkcjonuje w $\mathrm{P}$ jako odwrócenie porządku creatio: uwolnienie pierwotnych wód z Rdz 1,2 i cofnięcie wyznaczonych im granic. Natomiast sytuacja po potopie - przez użycie tych samych słów, formuł i obrazów - staje się wiernym naśladowaniem stwarzania. Bóg wyprowadza świat z potopu tak jak z pierwotnego bezmiaru wód: błogosławiąc ludzi i zwierzęta, nakazując im płodność, regulując dietę i przypominając o obrazie Bożym w człowieku. Temat potopu jako nowego stworzenia w $\mathrm{P}$ jest w egzegezie dobrze rozpoznany. ${ }^{12}$ Plagi egipskie (Wj 7-11) w redakcji źródła P są również

12 Zob.np. H. G u n k e 1, Genesis. Translated and Interpreted, tłum. M.E. B i d d l e, Mercer University Press, Macon 1997, s. 78n., 145n.; S.E. M c Eve n u e, The Narrative Style of the Priestly Writer, Anchor Bible 50, Biblical Institute Press, Roma 1971; W. B r u e g g e r m a n n, The Kerygma of the Priestly Writers, ZAW 84/1972, s. 397-413; D.L. P e te r s e n, The Yahwist on the Flood, VT 26/1976, s. 441; D.J.A. C 1 i n e s, Theme in Genesis 1-11, CBQ 38/1976, s. 499-502; t e n ż e, The Theme of the Pentateuch, JSOTSup 10, Sheffield Academic Press, Sheffield 1978, s. 61-77, zwł. s. 73-76; G. L a r s s o n, Chronological Parallels between the Creation and the Flood, Vetus Testamentum 27/1977, s. 490-492; t e n ż e, Remarks Concerning the Noah-Flood Complex, ZAW 112/2000, s. 75-77; J. K r a š o v e c, Punishment and Mercy in the Primeval History (Rdz 1-11), EThL 70/1994, s. 5-34, zw1. s. 21; E. F i r m a g e, Genesis 1 and the Priestly Agenda, JSOT 1999, s. 97-114; K. L o n ing, E. Z e n g e r, To Begin With, God Created... Biblical Theologies of Creation, The Liturgical Press, Collegeville 2000, s. 112-120; Ł. L a s k ow s k i, 
przedstawione jako odwrócenie porządku stworzenia, antykreacja. W wersji kapłańskiej każda z nich jest odniesiona do któregoś z dzieł stwórczych (np. stworzeniu światła odpowiada plaga ciemności itd.) jako jego antyteza. Bóg działa tu odwrotnie do swej kreacyjnej aktywności „na początku”. ${ }^{13}$ Faraon staje się głównym przeciwnikiem stworzenia, przez co na końcu doświadcza chaosu pierwotnych wód. Przejście przez Morze Sitowia (w LXX: Czerwone) także jest ukazane jako antykreacja w stosunku do Egiptu, a rekreacja w stosunku do Izraela. W rozdzieleniu wód dzieje się coś na kształt drugiego i trzeciego dnia stwarzania, gdy Bóg wyznaczał granice wodom najpierw przez ich podział na pół (wody górne i dolne), a potem przez ponowny podział wód tak, by ukazała się ,powierzchnia sucha” (יבשה). ${ }^{14}$ Taki obraz przedstawia jedynie kompozycja P, nie jest on obecny w warstwie niekapłańskiej (nP). Wcześniej, cudowny rozrost ludu Bożego w Egipcie (Wj 1,1-7) - ważny kapłański tekst w Księdze Wyjścia ${ }^{15}$ - to znów powrót do stwórczego błogosławieństwa płodności. Droga Izraela do Ziemi Obiecanej i doświadczanie na pustyni (Wj 16-18) to próbowanie, czyli test stworzenia. W końcu budowa sanktuarium Namiotu Spotkania pod Synajem (Wj 25-31 i 35-40) „W pierwszym dniu pierwszego miesiąca” - a więc „na początku" - stanie się nowym dziełem stwórczym Boga kreatora, dziełem, które niezwykle wiernie odwzorowuje kosmos i porządek

Motyw potopu jako nowego stworzenia w Biblii, Studia Biblica Lublinensia 7, Wydawnictwo KUL, Lublin 2010.

13 Szerzej M. M a j e w s k i, W stronę Ziemi Obiecanej, s. 158, 160, 178, 202.

14 Szerzej t e n ż e, Pięcioksiag odczytany na nowo, s. 261-266.

15 W najnowszych poszukiwaniach źródeł Pięcioksięgu duże zainteresowanie egzegetów przyciąga wyraźna luka między Księgami Rodzaju i Wyjścia, czyli między tradycją o patriarchach (Rdz), a tradycją o Mojżeszu i wyjściu (Wj). Znaczące różnice teologiczne, narracyjne i literackie między nimi interpretuje się jako wyraźny ślad dwóch pierwotnie niezależnych „mitów założycielskich” biblijnego Izraela. Tekst kapłański z Wj 1,7 jest tu jednym ze świadectw (pierwszego?) literackiego połączenia obu tradycji. Szerzej zob. np. T.B. D o z e m a n, K. S c h mid (red.), A Farewell to the Yahwist? The Composition of the Pentateuch in Recent European Interpretation, Society of Biblical Literature Symposium Series, Society of Biblical Literature, Atlanta 2006 (passim). 
opisany w Rdz 1: od podziału opisu na siedem części po określenia techniczne namiotu, które są tymi samym, jakie posłużyły do opisu konstrukcji świata. W optyce kapłańskiej sanktuarium JHWH na pustyni to mikrokosmos, nowe stworzenie, odnowiony porządek pierwotnej dobroci i świętości świata, a sprawowany w nim kult to nowy raj, gdzie Bóg, jak niegdyś, spotyka się z człowiekiem. ${ }^{16}$

Są to wybrane przykłady tekstów narracyjnych warstwy kapłańskiej, dla których teologia stworzenia stanowi żywą, kształtującą je tkankę. Egzegeci, którzy rozpoznają Rdz 1 jako supermit założycielski źródła kapłańskiego, stosują ów klucz interpretacyjny do tekstów narracyjnych $\mathrm{P}$, rzadko natomiast do prawniczych. A okazuje się, że również w tych stworzenie jest modelem, a świat wykreowany in illo tempore projektem do odtworzenia w prawie i w kulcie. Wszystko musi być zaprojektowane „według wzoru” niebiańskiego, stwórczego (zob. Wj 25,9; 25,40; 26,30; 27,8). ${ }^{17}$ Działanie Boga jest wzorcem (תבנית), zaś ideałem działania ludzkiego jest odtwarzanie go na ziemi. Boży odpoczynek staje się szabatem człowieka, a stworzenie świata jest imitowane w budowie ziemskiego sanktuarium JHWH. Podobnie prawo o Jom Kippur, czyli Dniu Pojednania (zob. Kpł 16 i 23) i o roku jubileuszowym (zob. Kpł 25) wprowadza do świata czas cyklicznego odnowienia stworzenia. Kapłańskie prawa o nieczystości śmierci i wszystkiego, co się z nią wiąże (Kpł 21; Lb 6; Lb 19), wynikają z postrzegania jej jako głównej przeciwniczki stworzenia. ${ }^{18}$ Także przestrzeganie kapłańskich praw seksualnych jest postrzegane jako uczestnictwo w akcie stwórczym Boga: uporządkowany przez

16 Szerzej M. M a j e w s k i, Mieszkanie Chwaty, s. 303-342.

17 W prawodawstwie kapłańskim pojawia się termin תבנית (,wzór”), oznaczający niebiański, stwórczy model, który Mojżesz ma odtworzyć na ziemi w postaci

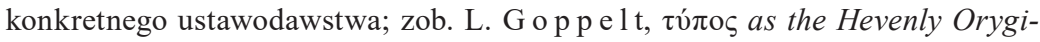

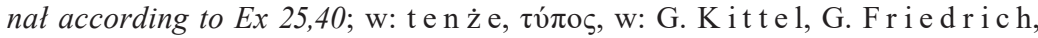
G.W. B r o m il e y (red.), Theological Dictionary of the New Testament, t. VIII, Eerdmans 1976, s. 246-259 (tu s. 256-259).

18 M. M aj e w s k i, Nieczystość śmierci w Torze, s. 31-63. 
prawodawcę $\mathrm{P}$ seks to czas na boskie kreacyjne działanie. ${ }^{19}$ Autor kapłański, rekonstruując prawodawstwo Izraela po trudnych doświadczeniach wygnania babilońskiego, chce je oprzeć na niewzruszonych i pewnych zasadach. Te odnajduje w supermicie kreacyjnym i wyrażonym w nim porządku stworzenia. Izraelskie prawo musi się opierać na tym paradygmacie.

Założyć należy, że podobnie jest w kwestii ukształtowania prawa pokarmowego Izraela. Przesłanki dla hipotezy, że prawem z Kpł 11 rządzi teologia stworzenia, pojawiły się we wczesnych pracach Mary Douglas $^{20}$ czy opracowaniu Jury Moskali, ${ }^{21}$ a w Polsce w pracy Jerzego Wasilewskiego ${ }^{22}$ - a więc w tekstach antropologów, a nie egzegetów. Antoni Tronina zapowiada we wstępie do analizy prawa pokarmowego, że „Kpł11 należy rozważać w świetle Rdz 1-3”, jednak w samym komentarzu brak tego odniesienia. ${ }^{23} \mathrm{~W}$ pracach antropologów temat kreacyjnej interpretacji prawa pokarmowego został zaznaczony, ale nie rozwinięty w kontekście teologii biblijnej czy teologii źródła kapłańskiego Pięcioksięgu.

\section{Stwórczy kontekst prawa pokarmowego}

Egzegeci rozpatrują przepisy z Kpł 11 zasadniczo w kontekście prawa o czystości: Kpł 11-15. To jest właściwe tło dla prawa pokarmowego, ale zbyt wąskie, żeby uchwycić istotę podziału zwierząt. Jacob

19 Te n ż e, Nieczystość seksu - biblijne zakazy dotyczące życia płciowego, w: M. S z m a j d z i ń s k i (red.), Gloriam praecedit humilitas (Prz 15,33). Księga pamiatkowa dla Ks. Prof. Antoniego Troniny w 70. rocznicę urodzin, Częstochowskie Wydawnictwo Archidiecezjalne, Częstochowa 2015, s. 391-414.

20 Zwłaszcza w M. D o u g l a s, Czystość i zmaza. Analiza pojęć nieczystości i tabu, tłum. M. B u c h o l c, PIW, Warszawa 2007.

${ }^{21} \mathrm{~J} . \mathrm{M} \mathrm{o} \mathrm{s} \mathrm{k}$ a $\mathrm{a}$, The Laws of Clean and Unclean Animals of Leviticus 11: Their Nature, Theology, and Rationale, Berrien Springs 1998.

22 J. W a s i le w s k i, Tabu, Wydawnictwa Uniwersytetu Warszawskiego, Warszawa 2010.

23 A. Tro n i n a, Księga Kapłańska. Wstęp, przekład z oryginału, komentarz, Nowy Komentarz Biblijny, t. 3, Edycja św. Pawła, Częstochowa 2006, s. 178. 
Milgrom - którego poglądy przedstawiłem krytycznie w poprzednim artykule serii - cofa się do pierwszej w porządku kanonicznym wzmianki o zwierzętach nieczystych, czyli do narracji o potopie, gdy Bóg zezwolił na spożywanie mięsa, lecz zakazał spożywania krwi. ${ }^{24}$ Także ta perspektywa wciąż jest niezadowalająca. Trzeba odwołać się do teologii całego źródła kapłańskiego, a jest to teologia oparta na prawach stworzenia. Prawo pokarmowe trzeba rozpatrzyć w kontekście, który można ująć w schemat: stworzenie - upadek - nowe stworzenie, czy jak go określa David Clines, „Creation - Uncreation Re-creation". ${ }^{25}$ Szczególnym elementem tego schematu są początkowe rozdziały Księgi Rodzaju z pierwszymi nakazami i zakazami pokarmowymi (Rdz 1) oraz kapłańska wersja potopu (Rdz 6-9).

Praprzodkowie z Księgi Rodzaju byli według P wegetarianami. Bóg bowiem dał człowiekowi jako pokarm wszelką roślinę: zboża, rośliny zielone i wszelkie rodzaje owoców. „Oto wam daję wszelką roślinę przynoszącą ziarno po całej ziemi i wszelkie drzewo, którego owoc ma w sobie nasienie: dla was będą one pokarmem" (Rdz 1,29). To jest pierwszy nakaz pokarmowy pojawiający się w Biblii i drugi Boży nakaz w ogóle (po poleceniu prokreacji w Rdz 1,28). Obfitość Bożego daru podkreśla dwukrotne użycie słowa כל:, „wszelkie”, „wszystkie”, „całość”. Na tym etapie dieta człowieka była podobna do diety zwierząt, które również miały być roślinożerne: „A dla wszelkiego zwierzęcia polnego i dla wszelkiego ptactwa w powietrzu, i dla wszystkiego, co się porusza po ziemi i ma w sobie pierwiastek życia, będzie pokarmem wszelka trawa zielona. I stało się tak" $(\operatorname{Rdz} 1,30){ }^{26}$

24 J. M i 1 g ro m, Leviticus 1-16, s. 704-713; t e n ż e, Ethics and Ritual. The Foundations of the Biblical Dietary Laws, w: E. B. F i r m a g e i in. (red.), Religion and Law. Biblical-Judaic and Islamic Perspectives, Eisenbrauns, Winona Lake 1990, s. 169.

25 D.J.A. C 1 i n e s, The Theme of the Pentateuch, JSOT Supplement Series 10, Sheffeld Academic Press, Sheffeld 1997, s. 81.

26 Niektórzy bibliści twierdzą, że narracja nP (jahwistyczna) o stworzeniu człowieka z Rdz 2 również zakłada wegetariańską dietę ludzi i zwierząt; zob. np. A. B r e n n e r, J.W. v a n Henten, Our Menu and What is Not On It. Editor's Introduction, w: c i ż (red.), Food and Drink in the Bible, Semeia 86, Scholars Press, 
To, że człowiek ma panować nad zwierzętami, oznaczało, że może je wykorzystać do pracy czy udomowić, ale nie zabijać i jeść. Bóg - jako Pan życia i Stwórca świata - rozporządza m.in. sposobem odżywiania się, ustala jadłospis oraz sam dostarcza pożywienie: „Każesz rosnąć trawie dla bydła i roślinom, by człowiekowi służyły, aby z roli dobywał chleb" (Ps 104,14).

Boże błogosławieństwo stworzenia to błogosławieństwo płodności, owocności dla roślin, to dar obfitego pokarmu. Generalnie w Biblii jest ono związane z życiem. Zasadniczym jego elementem jest m.in. żywność; Izaak tak błogosławi Jakubowi: „Niechaj tobie Bóg użycza rosy z niebios i żyzności ziemi, obfitości zboża i moszczu winnego" (Rdz 27,28). ${ }^{27}$ Także pierwszy w Biblii zakaz dotyczy pokarmu: „Z wszelkiego drzewa tego ogrodu możesz spożywać według upodobania, ale z drzewa poznania dobra i zła nie wolno ci jeść” (Rdz 2,16n.). Wcześniej Bóg zasadza ogród w Eden: „Na rozkaz Pana Boga wyrosły z gleby wszelkie drzewa rodzące smaczny owoc" i nakazuje człowiekowi, aby ,uprawiał go i doglądał” (Rdz 2,8n.15). Nie są to wprawdzie teksty tradycji P, ale na inny sposób wyrażają tę samą prawdę, że Panem odżywania się człowieka jest JHWH i to do Niego należy inicjatywa rozporządzania dietą ludzką i zwierzęcą. W obydwu tekstach pojawiają się też ograniczenia w diecie: w kapłańskim mowa o jedzeniu tylko roślinności, w niekapłańskim o zakazie spożywanie z drzewa poznania dobra i zła. Technicznie rzecz biorąc, to właśnie niewłaściwe z Bożej perspektywy jedzenie stało się przyczyną upadku człowieka i degradacji świata.

Idylla Edenu skończyła się równie tragicznie dla człowieka, jak i dla zwierząt. Po wygnaniu z raju okryciem człowieka stały się skóry zwierzęce (Rdz 3,21). Już św. Augustyn (w De Genesi contra Manichaeos, II) dostrzegał związek symboliczny między odzieniem

Atlanta 1999, s. ix. Nie jest to uzasadnione, choćby z uwagi na fakt, że według tego samego źródła Abel był chodowcą trzody $(\mathrm{Rdz} 4,2)$, a pierwsi rodzice nosili ubrania ze zwierząt $(3,21)$.

27 T.W. M a n n, Not by Word Alone. Food in the Hebrew Bible, Interpretation 67/2013, s. 352. 
ze skór a zapoczątkowaną śmiertelnością pierwszych ludzi: „Oni tak długo przebywali w raju, dopóki nie otrzymali odzienia ze skór, czyli śmiertelności życia doczesnego (...). Jakimż bowiem lepszym znakiem można było zapowiedzieć śmierć, którą czujemy w ciele niż przez skóry, które zwykle zdziera się z martwych zwierząt". ${ }^{28}$ Degradacja człowieka wygnanego z raju postępowała tak gwałtownie, że Bóg podjął decyzję o niszczycielskiej interwencji za sprawą potopu. Także tutaj ważną rolę odegrają prawa pokarmowe. Według tradycji kapłańskiej potop to czas, gdy świat na nowo pogrąża się w pierwotnych wodach, w przedstwórczym תהו ובהו. Wody, które zalewają świat to nie jest zwykły deszcz - jak w materiale nP $(7,12)$ - ale ,źródła wielkiej otchłani” (מעינות תהום רבה) oraz ,upusty nieba” (ארבת השמים) (7,11). Pojawia się tu dwa razy ten sam rzadki termin - תהום העום (7) (7,11 i 8,2) - który w Rdz 1 określa ,pierwotny ocean”, ,pramaterię” dominującą przed aktem stworzenia. Stwórcze działanie Boga polegało na wyznaczeniu przepastnym wodom stałych granic $(\operatorname{Rdz} 1,6.7 .9)$ - w historii potopu te granice zostaną usunięte. Potop stał się odwróceniem dzieła stworzenia, powrotem do czasu sprzed kreacji, gdy pierwotne wody dominowały (por. Rdz 7,4). Kolejny akt Boga to wyprowadzenie świata $\mathrm{z}$ kataklizmu, czyli nowe stworzenie. Stwórca działa tak, jak powoływał świat do istnienia: najpierw pojawia się ruah, Boży wiatr, który osusza ziemię (Rdz 8,1), następnie wody znów się oddzielają od ziemi $(8,2 n$.), różne gatunki zwierząt wychodzą na ląd i mają się tam rozmnażać (8,17n.), po czym następuje błogosławieństwo człowieka $(9,1)$ i przypomnienie, że został stworzony na obraz Boży $(9,6) .{ }^{29}$ Potop kończy się ,pierwszego dnia, pierwszego miesiąca”, a więc „na początku” nowego roku, rozpoczynając nowe dzieje świata $(8,13)$, a kategoria siedmiu dni jak echo powraca w całym opowiadaniu $(7,4 ; 8,10.12)$.

28 J.S. W a s i le w s k i, Tabu, zakaz magiczny, nieczystość, Etnografia Polska 31/1987, s. 35.

${ }^{29}$ Tę ostatnią analogię rozwija E. F i r m a g e, Genesis 1 and the Priestly Agenda, s. $101 n$. 
Bóg po potopie zezwala człowiekowi na jedzenie mięsa. Potomkowie Noego mogą jeść wszystko z taką swobodą, z jaką wcześniej prarodzice mogli jeść zieleninę: „Wszystko, co się porusza i żyje, jest przeznaczone dla was na pokarm, tak jak rośliny zielone, daję wam wszystko" (Rdz 9,3). Wegetariański stan ludzkości okazał się etapem. Nie był to - jak chcą niektórzy - stan idealny, a zgoda na jedzenie mięsa nie była ustępstwem Boga czy obniżeniem standardów. ${ }^{30}$ Bóg od samego początku przyjmował ofiary zwierzęce ( $R d z 4,4 ; 8,20$ -21) jako ,pokarm” i „miłą woń”. W opinii autora kapłańskiego nie ma nic nagannego w zabijaniu zwierząt czy jedzeniu mięsa. Zmiana w ludzkiej diecie, zarządzona przez Boga za czasów Noego, nie była pozwoleniem na ludzką słabość, nigdzie też nie mówi się o ludziach, że byli źli czy grzeszyli, dlatego że jedli mięso, ani że ich dieta mięsna jest wyrazem dekadencji. Przeciwnie, przez pozwolenie na jedzenie mięsa, człowiek został dopuszczony do sfery, która wcześniej była zarezerwowana dla Boga przyjmującego ofiary zwierzęce. Można powiedzieć nawet, że człowiek awansował, gdy zaczął jeść mięso. Jedynie spożywanie „krwi życia” zostało surowo zabronione (Rdz 9,4), bowiem ten atrybut życia należy w Biblii wyłącznie do JHWH, dawcy i Pana życia. Od tego czasu zwierzęta mają się lękać człowieka: „Wszelkie zaś zwierzę na ziemi i wszelkie ptactwo powietrzne niechaj się was boi i lęka. Wszystko, co się porusza na ziemi, i wszystkie ryby morskie zostały oddane w wasze ręce" (Rdz 9,2). Jeśli przed potopem człowiek i zwierzęta żywili się roślinnością i mogli żyć w przyjaźni, bez strachu i agresji po którejkolwiek ze stron, tak po potopie to pierwotne braterstwo zostało utracone na zawsze. Niektórzy badacze, nie bez racji, mówią o języku wojennym tego

30 Tezę, że spożywanie mięsa po potopie jest Bożą zgodą na ludzką słabość wysunął U. C a s s u t o, A Commentary on the Book of Genesis. Part One. From Adam to Noah, tłum. I. A b r a h a m s, Magnes Press, Jerusalem 1978, s. 58 (oryginalna wersja hebrajska: Magnes Press 1961). W tym duchu pisał Wasilewski: „Wtedy to Jahwe pogodzi się z ludzką niedoskonałością (Rdz 8,21) i niejako koncesjonując skłonność człowieka do niegodziwości i przemocy, zezwoli na zabijanie i zjadanie zwierząt”; J.S. W a s i le w s k i, Tabu, zakaz magiczny, nieczystość. 
wersetu. ${ }^{31}$ Obok panowania pojawia się strach, nieobecny w Rdz 1; zamiast świata współistnienia i pokojowej koegzystencji - świat walki o miejsce w świecie. Lęk stworzenia przed człowiekiem wyraża wrogą separację, a dodane do tego „oddanie w ręce” zapowiada stan napięcia i agresji. Kolejno pojawiają się zgoda na spożywanie mięsa zwierząt: „Wszystko, co się porusza i żyje, jest przeznaczone dla was na pokarm" ( $\mathrm{Rdz} 9,3)$ oraz ofiara ze zwierząt składana Bogu. Zwierzęta rzeczywiście muszą zacząć bać się ludzi.

\section{Kpł 11 jako synteza prawa pokarmowego Biblii}

Mimo że większość kapłańskiego materiału w Pięcioksięgu stanowi prawo i rytuał - skupiony zasadniczo w Księdzach: Wyjścia, Kapłańskiej i Liczb - to podstawą do zrozumienia tego specyficznego prawodawstwa jest kapłańska narracja mitohistoryczna z Księgi Rodzaju. Autor P nie tyle opisuje historię Izraela, ile tworzy dzieje Bożego uniwersalnego projektu - projektu odnowy. Zasadza się on na schemacie stworzenie - upadek - nowe stworzenie, w którym prawo o jedzeniu mięsa zwierząt z Rdz 9 przynależy do trzeciego elementu, jako przejaw odbudowywania ładu po potopie. To jednak nie będzie koniec regulacji pokarmowych. Pojawią się przepisy z Kpł 11, które będą wypadkową dwóch poprzednich skrajności: wegetarianizmu ( $R d z$ 1) i laksyzmu żywieniowego ( $R d z$ 9). Z propozycji jedzenia tylko roślin lub jedzenia wszystkiego autor kapłański wybierze ostatecznie rozwiązanie pośrednie, złoty środek.

31 Lohfink napisze: „The formulations «fear and dread», and «to deliver into someone's hand» are part of the language of war. In the oracle that is reflected here [Gen 9.2-3 - M.M.] the divinity gave the enemies «into the power» of those making war on them, and in the battle itself the god took part and thus threw the enemies into «fear and dread»"; zob. N. L o h f i n k, Theology of the Pentateuch: Themes of the Priestly Narrative and Deuteronomy, Fortress Press 1995, s. 13. Zobacz tez G. v o n R a d, Holy War in Ancient Israel, tłum. M.J. D a w n, Eerdmans, Grand Rapids 1991, s. 10-12; M. W e i p p e r t, ,Heiliger Krieg” in Israel und Assyrien, ZAW 84/1972, s. 460-493 (w przeciwieństwie do von Rada, Weippert wykazuje, że koncepcja świętej wojny w Izraelu nie jest specyficznie izraelską ideologią). 
Nowe Boże instrukcje co do diety człowieka, które pojawiają się w Kpł 11, będą stanowić ograniczenie w dostępie człowieka do świata zwierząt. W kontekście zarysowanej wyżej teologii kreacyjnej źródła kapłańskiego i w panoramie teologicznej prawa pokarmowego - przepisy o nieczystości zwierząt wybrzmiewają w nowy sposób. Jawią się jako kolejny, ostateczny już etap w Bożych instrukcjach żywnościowych i zawężenie prawa uniwersalnego do sytuacji narodu wybranego. Rdz 1 (nakaz spożywania roślinności) oraz Rdz 9 (zezwolenie na jedzenie wszystkiego) to prawo uniwersalne, natomiast Kpł 11 (zakaz spożywania zwierząt nieczystych) to prawo partykularne, narodowe. Zobaczmy teraz w szczegółach, jak prawo pokarmowe podejmuje wątki Rdz 1, by dowieść, że to właśnie normatywne teksty kapłańskie z Księgi Rodzaju mają decydujący wpływ na interpretację prawa pokarmowego, w tym na odpowiedź na pytanie o źródło i kryterium podziału zwierząt.

Pierwsze widoczne podobieństwo dotyczy podziału zwierząt w Kpł 11 na trzy kategorie: na zwierzęta lą d ow e (opisane w Kpł 11,2-8), w o d n e (opisane w Kpł 11,9-12) i p o w i e tr zn e (opisane w Kpł 11,13-23). ${ }^{32}$ Prawodawca stosuje zatem ten sam podział, jaki występuje w poemacie o stworzeniu Rdz $1 .{ }^{33}$ Tam trzy analogiczne przestrzenie - ziemia, wody i przestworza - najpierw są stwarzane, czyli rozdzielane, ${ }^{34}$ a potem ozdabiane istotami żyjącymi: stworzeniu wód i przestrzeni powietrznej (dzień 2) odpowiadają zwierzęta wodne i latające (dzień 5), a stworzeniu ziemi (dzień 3) zwierzęta lądowe i ludzie (dzień 6). Jest to znany w egzegezie Rdz 1

32 W zależnym od prawa pokarmowego z Kpł rozdziale Pwt 14 jest podobnie.

33 Zwraca na to uwagę m.in. H. E i $1 \mathrm{~b}$ e $\mathrm{rg}-\mathrm{S} \mathrm{c} \mathrm{hw} \mathrm{a} \mathrm{r} \mathrm{z,} \mathrm{Creation} \mathrm{and} \mathrm{Clas-}$ sification in Judaism. From Priestly to Rabbinic Conceptions, History of Religions 26/1987, s. 361, przyp. 11.

34 Pierwotne znaczenie czasownika ברא to „ciąć”, „odcinać”, „odkrajać”, ,przedzielać”, a dopiero potem „kształtować”, „formować”, „stwarzać” (tak Gesenius, Driver, Clines i inni). Szerzej np. W. G e s e n i u s, Hebräisches und aramäisches Handwörterbuch über das Alte Testament, Springer Verlag, Berlin-Göttingen-Heidelberg 1959, s. 129n.; E.J. v a n W old e, Why the verb ברא does not mean to create in Genesis 1, JSOT 34/2009, s. 3-23. 
podział na opus distinctionis („dzieło wyróżniania”), które obejmuje pierwsze trzy dni i opus ornatus („dzieło ozdabiania”), które charakteryzuje trzy pozostałe dni stwarzania. W Rdz 1 Bóg stwarza: niebo, morza i ziemię oraz ozdabia te przestrzenie zwierzętami: powietrznymi, wodnymi i lądowymi. Podział zwierząt w prawie pokarmowym podejmuje ten zasadniczy wzorzec zaczerpnięty z porządku stworzenia. ${ }^{35}$ Przypatrzmy się bliżej trzem wskazanym kategoriom i ich wykluczeniom.

\section{Dlaczego wykluczono niektóre zwierzęta lądowe?}

Co można wywnioskować z kryteriów parzystokopytności i przeżuwania (Kpł 11,3)? Co do kryterium przeżuwania wydaje się, że odnosi się ono do sposobu przyswajania i trawienia pokarmu, który wyklucza zwierzęta szarpiące pożywienie, a więc wszystkie mięsożerne, mające zęby do polowania i rozszarpywania. Przeżuwanie to specjalna forma dokładnego, kilkukrotnego naprzemiennego żucia i połykania pokarmu roślinnego, który wraca z żołądka, by być ponownie przeżuty. Przeżuwacze są wyłącznie roślinożercami. Zaś co do kopytności, Mary Douglas uważa, że kopyto odnosi się do sposobu poruszania się, jest atrybutem lokomocji. ${ }^{36}$ Ja sądzę inaczej. Kopyta zamiast łap nie wpływają istotnie na zmianę sposobu poruszania się po ziemi; jedna i druga grupa zwierząt mieści się „W normie”

35 Ten sam podział na trzy przestrzenie i trzy kategorie zwierząt jest także obecny w Ps 8,8-9: „Wszystko złożyłeś pod jego stopy: owce i bydło wszelakie, a nadto i polne stada, ptactwo powietrzne oraz ryby morskie, wszystko, co szlaki mórz przemierza”. Jednak Kpł 11 łączą inne ważne analogie z Rdz 1. Nawet jeśli przyjmiemy za M.P. C a r r o 11 (zob. One More Time. Leviticus Revisited, w: B. L a n g /red./, Anthropological Approaches to the Old Testament, Issues in Religion and Theology 8, Fortress Press, Philadelphia 1985, s. 117-126, tu s. 118) niewystarczająco uzasadniony pogląd, że zwierzęta w Rdz 1 dzielą się na pięć kategorii, a nie na trzy ryby, ptaki, bydło, dzikie zwierzęta lądowe i istoty pełzające (zob. Rdz 1,20.24) - to dalej w prawie pokarmowym znajdujemy taki sam podział i takie samo postrzeganie zwierząt (zob. Kpł 11,3.9.13.31.44).

36 M. D o u g l a s, Implicit Meanings: Essays in Anthropology, Taylor \& Francis, New York 2001²; t a ż, The Forbidden Animals in Leviticus, JSOT 59/1993, s. 11. 
lokomocji naziemnej (podobnie jak nie w lokomocji prawodawca upatrywał podziału na parzystokopytne i nieparzystokopytne czy taksonomię ptaków). Posiadanie kopyt wyklucza łapy - dlatego że łapy mają pazury, które służą najczęściej do polowania, zabijania i rozrywania pożywienia. A przecież mięsożerna dieta zwierząt jest niezgodna z porządkiem stworzenia. Nogi zwierząt lądowych mają mieć jedno przeznaczenie - mają służyć tylko i wyłącznie do przemieszczania się, biegania, do poruszania się. Zoologia potwierdza, że parzystokopytne są zwierzętami roślinożernymi (rzadziej wszystkożernymi), ale nigdy nie są mięsożerne. Mają żołądek jedno- lub wielokomorowy (żołądek przeżuwacza).

Kopytność więc wyklucza pazurzastość (broń do ataku), a przeżuwanie wyklucza jedzenie mięsa (zabijanie i rozszarpywanie). Wspólnym mianownikiem obu cech pożądanych u zwierzęcia jest roślinożerność - cecha wymagana od zwierząt rajskich. Oba kryteria selekcji zwierząt lądowych mają związek z dietą i ewentualnie sposobem zachowania się (przeżuwacze są z natury łagodniejsze) bardziej niż z lokomocją. Oba też są potrzebne, jako że jedno mogłoby być - jak w przypadku zająca, który tylko wygląda jakoby przeżuwał zwodnicze. To samo kryterium mięsożerności będzie wykluczać ptaki (o tym za chwilę). Dlaczego? „Dla wszelkiego zwierzęcia polnego i dla wszelkiego ptactwa w powietrzu, i dla wszystkiego, co się porusza po ziemi i ma w sobie pierwiastek życia, będzie pokarmem wszelka trawa zielona" (Rdz 1,30). Podobny pogląd wyrazi psalmista w Psalmie 104, wielkiej medytacji nad Bożym dziełem stworzenia: „Każesz rosnąć trawie dla bydła” (Ps 104,14). Taką samą sytuację przepowie prorok Izajasz w przyszłym królestwie Bożym, gdzie dieta zwierząt również będzie bezmięsna: „Lew jak wół będzie jadał słomę" (Iz 11,7b). Pożądanym zwierzęciem świata idealnego jest to, które zachowuje dietę rajską. Zwierzęta, które jedzą siebie nawzajem, nie mieszczą się w harmonii stworzenia. I nie chodzi tylko o zabijanie i mięsożerność, ale także o spożywanie krwi, która dla prawodawcy, zwłaszcza kapłańskiego, jest silnym tabu (zob. Rdz 9,3-4 i Kpł 11,10-14). Źródło P najsurowiej zakazuje spożywania krwi. 
Obie cechy zwierząt czystych - parzystokopytność i przeżuwanie - wzięte razem określają taką grupę istot lądowych, jaka - zdaniem prawodawcy - żyła w raju. Kryteria są kryteriami stwórczymi i zmierzają do odtworzenia w życiu codziennym i kulcie pierwotnej harmonii, jaka panowała po stworzeniu. Tak samo będzie z eliminacją jakiejkolwiek postaci śmierci przez naznaczenie wszystkiego, co się z nią wiąże etykietą tame („nieczyste”) - stwórczy porządek jest porządkiem życia; w raju nie było śmierci. Połączenie tych dwóch kryteriów prowadzi do zaakceptowania dwóch rodzajów zwierząt: domowych oraz dzikich roślinożerców, które generalnie są łagodniejsze i bardziej przyjazne niż drapieżniki. Zachowany jest przez to szacunek wobec życia i zakaz zabijania oraz spożywania krwi. Zwierzęta zabijające i zjadające inne, spożywające padlinę i krew symbolizują porządek chaosu, stan przeciwny do porządku stworzenia i uosabiają - jak faraon w epopei Wyjścia - siły przeciwne stworzeniu. ${ }^{37}$

Drapieżniki nie spełniają obu cech, w ich przypadku sprawa jest więc jasna. Cztery wspomniane przez prawodawcę przykłady zwierząt nieczystych - wielbłąd, świstak, zając i świnia - to przypadki bardziej złożone. To gatunki, które albo mają podwojone kopyto, albo przeżuwają, nigdy jednak nie mają obu tych cech na raz. W związku z tym także im nie udaje się zakwalifikować do klasy parzystokopytnych przeżuwaczy. Świnia jest anomalią samą w sobie. Jak ustalił Hunn, spośród 91 znanych na Bliskim Wschodzie gatunków zwierząt, które nie przeżuwają, świnia jest jedynym parzystokopytnym;

37 Douglas miała inną wizję. Według niej te dwa warunki - parzystokopytność i przeżuwanie - wynikały z tego, że dla prawodawcy wzorem była tu owca. Autorka przypomina, że dawni Izraelici byli pasterzami owiec, którzy zapewne nie gustowali w zwierzynie łownej. Nie jest to zresztą kwestia gustów kulinarnych, lecz raczej pasterskiego etosu - być zmuszonym do jedzenia dziczyzny to znak, że jest się złym pasterzem. Wzorem właściwego pożywienia było najlepiej znane im zwierzę, owca. Ona też stanowiła model zwierzęcia czystego i jeśli już Izraelici jedli mięso dzikich zwierząt - np. antylopy, jelenia - to musiały one mieć zasadnicze cechy charakterystyczne owcy. Ta zaś jest oczywiście parzystokopytnym przeżuwaczem; t a ż, Czystość i zmaza. 
odpowiednio spośród 11 parzystokopytnych - jedynym nieprzeżuwającym. ${ }^{38}$ Pozostaje pytanie: Dlaczego prawodawca z kopytnych wyklucza te o nierozdzielonym, pełnym kopycie, tzw. nieparzystokopytne? Są to przede wszystkim domowe zwierzęta roślinożerne: wielbłąd, osioł, koń i muł, a z dzikich np. słoń, nosorożec czy zebra. Wszystkie one nie spożywają przecież krwi, nie są odrażające przez zabijanie czy dietę mięsożerną, a poruszają się zgodnie z normą własnego środowiska. Naszą uwagę powinni zwrócić zwłaszcza domowi popularni w Palestynie roślinożercy, gdyż dzikie zwierzęta, jak słoń czy nosorożec, nie mieszkały w bliskim sąsiedztwie Izraela i najprawdopodobniej w ogóle nie wchodziły w rachubę prawa pokarmowego. Co innego w przypadku zwierząt tak bliskich pasterskiemu życiu człowieka Wschodu, jak osioł, wielbłąd, koń czy muł. Najprawdopodobniej to ze względu na te właśnie cztery gatunki prawodawca dodał kryterium parzystokopytności. Wszystkie je bowiem uważał za nierozdzielnokopytne. ${ }^{39}$

Nie ma prostej odpowiedzi na to pytanie - które jakoś umyka egzegetom i antropologom - jednak nasuwa się możliwość zgodna z logiką porządku creatio. Otóż, tak jak inne stworzenia, gwiazdy, wody, sklepienie, rośliny itd., tak również zwierzęta mają określoną w akcie stwórczym funkcję w świecie ludzkim (np. gwiazdy mają „oddzielać dzień od nocy, wyznaczać pory roku, dni i lata”, Rdz 1,14). W tym przypadku wielbłąd, osioł, koń i muł mają funkcję transportową, a nie żywieniową. Zwierzęta te miały być wykorzystywane wyłącznie jako transport i pomoc przy domu, a nie jako hodowla na mięso. To dlatego prawodawca dodał kryterium parzystokopytności i wykluczył je z listy zwierząt jadalnych. Dla niego bowiem stworzenie tych gatunków wiązało się $\mathrm{z}$ ich przeznaczeniem. Wymienione zwierzęta stanowiły wielką pomoc w gospodarstwie domowym i w codziennym życiu człowieka Wschodu - tak jest miejscami do dnia dzisiejszego - w związku z czym nie mogły być dodatkowo

38 J.S. Wa si 1 e w s k i, Tabu, s. 99.

39 O błędnej w tym względzie klasyfikacji wielbłąda pisałem w pierwszym artykule tej serii. 
wykorzystywane do innych, niezgodnych z ich funkcją celów. To typowe zwierzęta transportowe i pociągowe, przeznaczone i świetnie przystosowane przez naturę do ciężkiej pracy, dalekich podróży i udogodniania życia człowiekowi swą siłą, mądrością, wytrzymałością i innymi podobnymi cechami. Do tego celu zostały stworzone i to w oczach prawodawcy wyklucza je z niezgodnego z ich przeznaczeniem użytkowania. Jeśli patrzymy na reguły nieczystości jako na wypatrzone przez prawodawcę zakłócenia w świecie jednoznacznych stanów i kategorii, to zwierzęta pociągowo-użytkowe muszą być wykluczone z dodatkowego, niezgodnego z ich rolą wykorzystania. Dodatkowo muł jest mieszańcem (konia i osła), hybrydą, co wyklucza go także $\mathrm{z}$ tego powodu (o tym jeszcze poniżej).

Zwierzęta udomowione i oswojone (jak psy, koty, konie, osły) bywają żywieniowym tabu w wielu kulturach. Wydaje się, że człowiek czuje się za bardzo związany emocjonalnie ze zwierzęciem, z którym na co dzień spędza wiele czasu, by móc je jeść. Być może też prawodawca wzorował się kopytem najlepiej znanych sobie zwierząt bydła domowego, które wymieniane jest jako pierwsze w stwórczym dziele Boga: „Niechaj ziemia wyda istoty żywe różnego rodzaju: bydło, zwierzęta pełzające i dzikie zwierzęta" (Rdz 1,24). Wzorem właściwego kryterium mogły tu być parzystokopytne krowa i owca, najlepiej znane Izraelitom zwierzęta hodowlane. Wzorowanie się na bydle mogło sprawić, że wybrano kryterium rozdwojonego kopyta, a nie kopyta w ogóle.

\section{Dlaczego wykluczono niektóre zwierzęta wodne?}

Mimo że kryterium mięsożerności jest w prawie pokarmowym bardzo istotne, nie jest jednak jedyne. Nie obejmuje wszystkich zakazanych zwierząt (jak choćby zwierząt wodnych, rojących się w powietrzu czy wodzie oraz pełzających po ziemi). Te muszą być osobno wyjaśnione. Douglas, dostrzegając w przeżuwaniu kryterium mięsożerności, wszystkie inne zwierzęta nieczyste sklasyfikowała 
jako „ofiary” drapieżnych zwierząt. ${ }^{40}$ Według niej są one uszkodzone, niedoskonałe - a Kpł 24,19 daje dowód, że wadą może być także podatność na atak, wada może być rozumiana jako rezultat ataku. Zatem zwierzęta, które ulegają napaści drapieżników, same są niedoskonałe. Badaczka ma tu na myśli analogię ze świata ludzkiego: żebracy, sieroty i bezbronne wdowy. ${ }^{41}$ Te zwierzęta reprezentują to, co biedne, słabe i podatne na zranienia - i dlatego jest kwestią współczucia oszczędzanie ich. Na początku artykułu powołuje się na Ps 145,9: „Pan jest dobry dla wszystkich i Jego miłosierdzie ogarnia wszystkie Jego dzieła". Teoria ta jest nieprzekonująca; znajduje się pod istotnym wpływem antropologii społecznej Durkheima (zwierzęta jako symbol ludzi), ${ }^{42} \mathrm{z}$ której to pozycji autorka w ostatnich publikacjach stopniowo się wycofała.

Kryterium dla ryb jest posiadanie płetw i łusek. Pierwsze są środkiem lokomocji, poruszania się, lecz drugie to raczej środek obronny, ochronny, maskujący, ewentualnie zmniejszający opór ciała

40 M. D o u g l a s, The forbidden animals in Leviticus, s. 18.

${ }^{41}$ Tamie, s. 22: „The forbidden animals species exemplify the predators, on the one hand, that is those who eat blood, and on the other, the sufferers from injustice. Consider the list, especially the swarming insects, the chameleon with its lumpy face, the high humped tortoise and beetle, and the ants labouring under their huge loads. Think of the blindness of worms, and bats, the vulnerability of fish without scales. Think of their human parallels, the labourers, the beggars, the orphans and the defenceless widows”. I dalej autorka podsumowuje: „Though this interpretation makes the dietary rules symbolic for virtues and vices, the permitted animals do not stand for any virtues, they simply keep the rule of avoiding blood, and the forbidden animals do not represent vices in their own bodies, but the effects of vicious actions on part of others" (s. 23).

42 W pracach antropologów nt. klasyfikacji zwierząt - jak Douglas o Kongo (1966), Bulmera o Nowej Gwinei (1967) czy Tambiaha o północno-wschodniej Tajlandii (1969) - widać, jak jest ona silnie związana z odniesieniami społecznymi. Podział natury, podział zwierząt odzwierciedla i wzmacjani społeczne zasdy zawierania małżeństw i zamieszkiwania. Chodzi o to, że człowiek w naturze społeczny tworzy kategorie, które odróżnią jego własną społeczność od innych konkurencyjnych światów, które wyznaczą granice między tym, co w środku, a tym, co na zewnątrz, między tym, co nasze, a tym, co obce; M. D o u g l a s, Ukryte znaczenia, s. 372 . 
w wodzie. Często powtarzaną opinią jest ta, że Izraelici uważali bezpłetwowce i bezłuskowce za odrażające ze względu na ich podobieństwo do węży, i że najważniejszą koncepcją w prawie pokarmowym było odróżnienie ryb od węży i wężopodobnych (jak węgorz, sum czy murena). ${ }^{43}$ Jednak w przepisie tym równie dobrze może chodzić o brak cech charakterystycznych dla zwierząt z własnej rodziny i środowiska. Kolejną bowiem kategorią stwórczą - po roślinożerności zwierząt - jest ich podział według właściwych im siedlisk życiowych oraz posiadanie cech właściwych dla swego środowiska życia. Królestwem ryb są wody, a w wodzie do poruszania się i ochrony służą przede wszystkim płetwy i łuski. To są dla prawodawcy istotne cechy królestwa ryb. Dlatego ich posiadanie jest wymagane od czystych zwierząt wodnych.

Co ciekawe, brak tu kryterium, które wykluczałoby ryby mięsożerne, w związku z czym niektóre z czystych ryb są rybożercami. Ta cecha nie stanowi najwyraźniej dla prawodawcy żadnego problemu, ponieważ nigdzie w Pięcioksięgu nie ma zakazu spożywania przez ludzi rybiej krwi. Nie ma także przepisów nt. przelewania/ spuszczania krwi ryb czy jakichś specjalnych instrukcji co do ich uboju. Analogicznie więc nie ma nic niestosownego dla jednych ryb, które - jak szczupak, dorsz czy łupacz - połykają inne ryby (w ten sposób żadna krew nie pojawia się w wodzie). Nie jest też pewne, czy Izraelici potrafili rozpoznać i rozróżniać dokładnie, które ryby są mięsożerne.

W trzech wersetach o rybach w Kpł 11,10-12 aż czterokrotnie nieשקץ („obyste nazwane sądliwość”). Wszystko, co nieczyste, wywołuje obrzydzenie i wstręt, ponieważ prowadzi do wyłączenia człowieka z udziału w kulcie i z życia społecznego. Wstręt ma być tu reakcją obronną wobec rzeczywistości, która zakłóca porządek stworzenia. Termin שקץ nie oznacza obrzydliwości w sensie estetycznym, gdyż te same zwierzęta, które w prawie pokarmowym nazwane są szekec, niejednokrotnie w Biblii cieszą się wielkim szacunkiem, np. kruk (Rdz 8,7; 1Krl 17,6) czy orzeł (Hi 39,27-30; Iz 40,31). Chodzi

\footnotetext{
43 Tak np. J. M o s k a 1 a, The Laws of Clean and Unclean, s. 331.
} 
o „obrzydliwość” na poziomie rytualnym, o wyuczenie odruchu dystansu wobec istot znajdujących się poza zakreślonym przez Boga porządkiem stwórczym.

\section{Dlaczego wykluczono niektóre ptaki?}

Co do ptaków, nie podano żadnego wykluczającego kryterium anatomicznego. Wymieniono po prostu gatunki nieczyste: dwadzieścia w Księdze Kapłańskiej, a dwadzieścia jeden w Księdze Powtórzonego Prawa. Obie listy praktycznie się pokrywają, ale nie do końca; w sumie otrzymujemy 24 nazwy gatunków czy lepiej rodzajów ptaków. Mówienie o „rodzajach”, a nie gatunkach, ptaków wynika z faktu, że Izraelici nie rozróżniali dokładnie poszczególnych gatunków między pewnymi rodzinami (np. rodzinę ptaków z rzędu sokołowate: falconidae, z których aż 25 gatunków spotykamy w Palestynie, traktowali prawdopodobnie jako jeden gatunek). W związku z tym część określeń może dotyczyć nie pojedynczych gatunków, ale rodzin i grup ptaków, których prawodawca nie rozróżniał tak szczegółowo, jak robi to dzisiejsza ornitologia. Zgadza się to z kilkukrotnym w tej części prawa stwierdzeniem autora „wszelkie gatunki sępa, orła...”.

W pierwszym artykule tej serii przytoczyłem analizy, które wskazują, że wymienione gatunki ptaków nieczystych to najbardziej popularni mięsożercy i padlinożercy Palestyny (ostatni nietoperz - chociaż jest to ssak - stanowi anomalię samą w sobie ze względu na nieopierzenie, nieskładanie jaj i specyficzny sposób spoczynku - głową w dół). To, że kryterium wykluczenia dla ptaków była ich mięsożerność, dostrzegano już w starożytności, m.in. w Liście Arysteasza i w Misznie. Jeśli lista ptaków nieczystych jest kompletna - co jest najbardziej prawdopodobne - to możemy stwierdzić, że racjonalnym powodem wykluczenia był - jak w przypadku zwierząt lądowych ich niejarski sposób odżywiania się. Znów chodzi o wykluczenie polujących, czyli zabijających oraz jedzących mięso z krwią, padlinę. 
Z niemal 350 gatunków ptaków znanych w Palestynie ${ }^{44}$ ok. 1/3 mogła żywić się gryzoniami lub małymi kręgowcami ${ }^{45}$ Nie wszystkie te gatunki były znane Izraelitom żyjącym na wyżynach centralnych. Na przykład ptaki nadbrzeżne, wśród których 18 gatunków żyje w Palestynie, były raczej nieznane.

Dlaczego w tym jedynym przypadku nie podano cechy wykluczającej? Z tego prostego powodu, że starożytnemu prawodawcy bardzo trudno było znaleźć takie kryterium anatomiczne, które jednoznacznie odróżniałoby pożądaną grupę ptaków. Jedyny raz w prawie pokarmowym posłużył się więc wyliczeniem najpopularniejszych gatunków znanych ówczesnym mięso- i padlinożerców, co było łatwiejsze i czytelniejsze. Autor wolał wyliczyć nieczyste, gdyż podanie kryterium mięsożerności byłoby być przydatne jedynie dla ekspertów. Przeciętny człowiek mógł mieć wielkie problemy z określeniem, który ptak jaką stosuje dietę. Podanie samego kryterium wprowadziłoby wiele niejasności i konsternację. Dlatego prawodawca wolał wymienić wszystkie, jakie znał i jakie były najpopularniejsze latające mięsożerne. ${ }^{46}$ Jest to jednocześnie najszersza lista ptaków, jaką dysponuje Biblia.

Wykluczone ptaki są drapieżnikami, można założyć, że wszystkie z nich. Jest jasne, że różnią się one zasadniczo od innej grupy ptaków dobrze znanych prawodawcy, jakimi są ptaki udomowione. Te nie jedzą mięsa, zawsze są ziarnożerne jak gołąb, trawo/roślinożerne jak gęś czy wszystkożerne jak kaczka. To, co na pewno łączy ptaki udomowione i jednocześnie odróżnia je od grupy mięso- i padlinożerców, to ich towarzyskie usposobienie. Zastosowane przez Douglas kryterium właściwych środków lokomocji powinno wykluczyć

44 Pełna lista zob. w H.B. Tr i s $\mathrm{r}$ a m, Survey of Western Palestine, Committee of the Palestine Exploration Fund, London 1885, rozdz. Fauna and Flora, s. 30-139.

45 Podręczny, krótki opis diety ptaków wymienionych przez Tristrama można znaleźć np. w Encyclopaedia Britannica.

46 Nie zrobił tak w przypadku zwierząt lądowych i wodych, gdyż tam musiałby wymieniać dziesiątki lub setki gatunków, znacznie praktyczniej było podać cechę (ewentualnie uzupełnić ją o wykaz gatunków na pewno jadalnych, jak zrobiono to w Pwt 14,4-5). 
zwierzęta takie, jak kura czy kaczka, jednak w przypadku ptaków prawodawca zastosował jedynie stwórcze kryterium właściwej diety. Te ptaki nie zostały więc wykluczone.

Do ptaków dołączono owady latające, zapewne ze względu na posiadanie skrzydeł i latanie (Kpł 11,20.21.23). To są tzw. שרץ העוף „rojące się latające” (jak szerszenie, pszczoły, muchy itp.). Ich nie dotyczy kryterium, które odróżniało ptaki, czyli dieta. Wyklucza je natomiast kryterium bardziej oczywiste - zbyt radykalnego odróżniania się od wzorca zwierząt powietrznych, z którego się wywodzą i w którym żyją. Są w sposób oczywisty różne od głównych reprezentantów swej grupy, czyli od ptaków, nie przypominają ptaków, do których środowiska zalicza ich prawodawca. Podobnie autor Kpł 11 traktuje owady bezskrzydłowe, naziemne - są wykluczone przez swe niepodobieństwo do istot lądowych, zbyt małe rozmiary, niejadalność itp.

Pisarz kapłański wprowadza tu jeden praktyczny wyjątek: szarańczę (Kpł 11,22). Jej gatunki są dozwolone w diecie wyraźnie na zasadzie ustępstwa czy wyjątku - co przyznają wszyscy badacze. Widać to po wymienieniu - wyjątkowo w całej perykopie i nietypowo dla Kpł 11 - nazw trzech dozwolonych gatunków szarańczy. Te gatunki, podobnie jak inne owady latające, nie spełniają kryteriów, powinny zatem należeć z innymi skrzydlatymi szeracim do nieczystych, ale prawodawca przyznaje im na zasadzie swej władzy ustawodawczej koncesję, prawo spożycia i cechę czystości. Powodów tego ustępstwa w prawie można się jedynie domyślać, gdyż nie zostały podane. Powszechnie przypuszcza, że było to wyjście naprzeciw biednym, dla których szarańcza była ważnym składnikiem diety (tak np. Milgrom, ${ }^{47}$ Wenham, Tronina). Ci, którzy podważają

47 J. M i 1 g r o m, Leviticus 1-16, s. 666: „The reason for exempting the locusts is not clear"; zob. tamże, s. 664-666, 734-735: „This law goes beyond any system of an explanation of the Pentateuchal dietary laws and is a fine indication of a sovereign decision of a Holy God in regard to the distinction between clean and unclean animals/food. One cannot squeeze all dietary regulations into one simplistic theory. However it is interesting that the element of locomotion is stressed in this legislation (they walk on all four legs, but also can hop)". 
podział klasowy w spożywaniu szarańczy, wskazują na jej popularność, zwłaszcza jako dostępne źródło niedrogich protein w pewnych okresach ubogich w inne źródła białka (Bodenheimer, Firmage). ${ }^{48}$ Beduini na Synaju oraz Półwyspie Arabskim do dziś żywią się szarańczą, także jemeńscy Żydzi jedzą smażone szarańcze.

\section{Pozostałe wykluczenia $\mathrm{z}$ diety}

Widzimy, że każdemu z trzech żywiołów - ziemi, wodzie i powietrzu - przypisany jest właściwy sposób poruszania się zwierząt. Każda klasa zwierząt musi mieć cechy morfologiczne umożliwiające przemieszczanie się właściwe swemu żywiołowi i dniowi stworzenia, do którego należy. Zwierzęta, którym np. brakuje organów ruchu stosownych do zamieszkiwanego środowiska albo mają je w nadmiarze, zostają wykluczone: „Każda istota wodna, która nie ma płetw albo łusek... będzie dla was obrzydliwością. (...) Wszystko, co lata, a porusza się na czterech nogach, będzie dla was obrzydliwością. (...) Wszystkie latające owady czworonożne będą dla was obrzydliwością. (...) Cokolwiek pełza na brzuchu, cokolwiek chodzi na czterech nogach i cokolwiek ma wiele nóg spośród małych zwierząt pełzających po ziemi, nie będzie przez was jedzone, bo to jest obrzydliwość" (Kpł 11,10.20.23.42). Oprócz diety jest to podstawowe kryterium, jakim kieruje się prawodawca.

Niektóre zwierzęta jasno da się sklasyfikować, np. lądowe, wodne czy powietrzne. Inne z kolei są wyzwaniem dla zwykłej klasyfikacji. Istnieją zwierzęta nie dające się poddać klasycznej taksonomii: ssaki, które latają jak ptaki, zwierzęta lądowe mieszkające w wodzie,

48 Choć rzeczywiście szarańcza była ważnym artykułem żywienia dla ubogich, jednak kwestia jej spożywania nie jest jedynie sprawą klasy, stanu społecznego czy zasobności. W Kpł 11 mamy najprawdopodobniej do czynienia z czymś więcej niż ustępstwem wobec biednych. Trzeba brać pod uwagę długo utrzymywaną popularność szarańczy jako taniego źródła protein w okresach, gdy pojawia się w chmarach. Nie ma chyba bardziej efektywnego kosztowo i żywieniowo rodzaju pożywenia. Gdy pojawiała się szarańcza i zajdała ludzkie plony, to zjedzenie jej w zamian mogło być jedyną rekompensatą, by uniknąć widma głodu. 
zwierzęta wodne zamieszkujące na lądzie - wszystkie one zostają wykluczone. Prawodawca zakazuje spożywania niektórych zwierząt ze względu na trudność zakwalifikowania ich do którejś ze znanych kategorii. Żółw np. jest zwierzęciem lądowym, ale składa jaja i ma skorupę, która odróżnia go od innych lądowych stworzeń. Podobnie łuskowaty ogon i pokrycie pancernika. W każdym nawet najprostszym systemie klasyfikacji pewne zwierzęta będą wykazywały jakieś anomalie. Ich niezgodne $\mathrm{z}$ ogólnymi zachowania i budowa ciała stanowią wyzwanie dla prawodawcy i powód do wykluczenia. Wszystko, co anomalne w porządku stworzenia, nie mieści się w kategorii „,czystego”. Z jadłospisu Izraelitów wykluczono zwierzęta o niestandardowej budowie: czy to naziemne, a np. bez nóg, czy to wodne, a bez płetw, czy te o niespotykanym, dziwnym wyglądzie, jak krewetki, kraby, homary, czy niestandardowym sposobie poruszania się, jak foki, czy wreszcie ptaki bez dwóch skrzydeł i dwóch nóg itd. Należą do wykluczonych wszystkie mięczaki (ślimaki, ośmiornice, ostrygi, małże - druga największa z gromad zwierząt na świecie z liczbą ok. 120 tys. gatunków), pająki i inne owady. Dla prawodawcy nie są to ani zwierzęta lądowe, ani ryby, ani ptaki. Te zwierzęta zbyt odróżniają się od reprezentantów swych grup. Wykluczono je także dlatego, że bardzo często łamią granice swego środowiska (żyjąc np. jednocześnie w wodzie i na lądzie).

Pełna lista wykluczeń pokarmowych ujawnia arbitralność prawa. Nie ma potrzeby zastanawiać się, czy każdy członek społeczności przestrzegał jadłospisu ze świadomością, co się za tym kryje. Zasady społeczne są interioryzowane przez członków społeczności zanim pozna się argumentację stojącą za nimi i często zupełnie w oderwaniu od jakiejkolwiek argumentacji. Po prostu takie są zasady. Pewne zwierzęta są nieczyste i się ich nie je. Dlaczego? To pytanie nie ma sensu, tak jak pytanie, dlaczego woda jest mokra - po prostu jest. Zapewne, gdybyśmy zapytali starożytnych Izraelitów, dlaczego przestrzegają tego podziału i dlaczego pewne zwierzęta uważają za nieczyste, niespecjalnie potrafiliby wyjaśnić symbolikę owych zachowań. Autor kapłański także nie wykłada wprost swych założeń, 
wierny ezoterycznemu językowi całego swojego piśmiennictwa. ${ }^{49}$ Przekonanie, że nieczystość jest niebezpieczna, jest w dużej mierze przekonaniem ukrytym, jest niejako podświadome. Coś po prostu jest nieczyste i człowiek nie pyta dlaczego. My także przestrzegamy pewnych reguł i norm nie zawsze uświadamiając sobie, dlaczego to robimy i czy uzasadnienie jest na pewno racjonalne.

\section{Stwórczy zakaz mieszania i lamania granic}

Tak dochodzimy do określenia kolejnej kategorii stwórczej ujawniającej się w prawie pokarmowym, jaką jest zasada granicy oraz normy. W opisie stworzenia i prawie pokarmowym mamy trzy klasy zwierząt: lądowe, wodne i powietrzne, z których każda porusza się w ramach swego własnego środowiska naturalnego. W kapłańskiej kosmologii w Rdz 1 te środowiska mają czytelnie wyznaczone przez Boga granice. Na tym polegało stwarzanie - na rozdzielaniu i wyznaczaniu delimitacji. Cokolwiek permanentnie łamie ustalone w akcie stwórczym granice i przekracza własne obszary, jest wyłączone z listy czystych, jadalnych zwierząt. Owe granice dotyczą nie tylko fizycznego miejsca poruszania się. To także normy, które spełniać musi dana kategoria zwierząt, normy co do budowy morfologicznej, sposobu zachowania się, poruszania, jedzenia itd. Nieczyste są zwierzęta, które nie spełniają kryteriów własnego środowiska, wyłamują się z grupy, do której należą, łamią wyznaczone przez Boga w stworzeniu granice i wykraczają poza boską normę.

Wiemy, że Bóg w Rdz 1 stwarza przez rozdzielanie. Czasownik היבדל (,rozdzielił”) pojawia się w pięć razy w różnych częściach

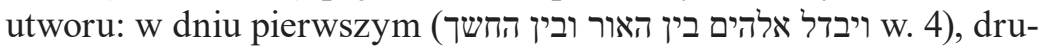

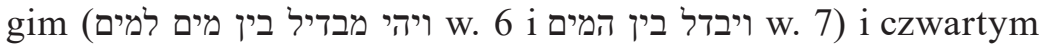
להבדיל בין היום ובין הלילה למים w. להבדיל בין האור ובין החשך w. 14. 18). Do tego,

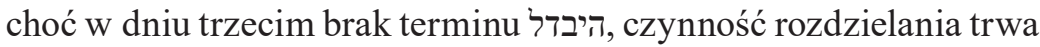
nadal: „Niechaj zbiorą się wody spod nieba w jedno miejsce i niech się

49 O ezoterycznym języku źródła P zob. M. M a j e w s k i, Pięcioksiąg odczytany na nowo, s. 71-76. 
ukaże powierzchnia sucha" (w. 9). Podział pojawia się także w dniu szóstym, gdy człowiek definiowany jest jako mężczyzna i kobieta, oraz w dniu siódmym, gdy Bóg wyodrębnia święty dzień szabatu, czyniąc ,świętym”, czyli oddzielonym od innych dni tygodnia $(2,3)$. Stwórcza czynność rozdzielenia pojawia się także w prawie pokarmowym. Ma ono polegać właśnie na rozdzieleniu i rozróżnianiu, jakie Bóg poczynił między zwierzętami czystymi i nieczystymi. Bóg nakazuje wcześniej: „,...abyście rozróżniali między tym, co święte, a tym, co świeckie, między tym, co nieczyste, a tym, co czyste" (Kpł 10,10). Ten sam nakaz, i ten sam stwórczy czasownik, pojawia się w podsumowaniu prawa pokarmowego: ,...abyście rozróżniali między tym, co nieczyste, a tym, co czyste, między zwierzętami jadalnymi a tymi, których jeść nie wolno" (Kpł 11,47). Gdy autor na innym miejscu powróci do nakazów pokarmowych, ponownie silnie złączy je z rozkazem odróżniania: „Będziecie odróżniać zwierzęta czyste od nieczystych, ptaki nieczyste od czystych. Nie będziecie plugawić siebie samych przez zwierzęta i ptaki ani przez wszystko, co się roi po ziemi, przez wszystko, co oddzieliłem od was jako nieczyste" (Kpł 20,25). W Kpł 20,24-26 termin היבדל pojawi się aż cztery razy. ${ }^{50}$ Idea rozdzielania, kluczowa dla dzieła stwórczego, jest programowa także dla prawa pokarmowego. To wyróżnia prawodawstwo Kpł 11 i łączy je z mitem stwórczym, wskazując, że ta sama aktywność Boża - separowanie - towarzyszy stwarzaniu, jak i kategoryzowaniu zwierząt jadalnych. W stworzonym świecie wszystko było uporządkowane i niepomieszane. Ułożone na swoim miejscu. Bóg rozdzielił światło od ciemności, wody górne od dolnych, ziemię od morza itd. W Kpł 11 to Izrael jest powołany do tego, by rozsądzać i rozdzielać: ,....abyście rozróżniali między tym, co nieczyste, a tym, co czyste, między zwierzętami jadalnymi a tymi, których jeść nie wolno”. Gdy ludzie rozróżniają między czystym, a nieczystym, naśladują Boga w jego aktywności stwórczej. W rozsądzaniu Izraelici wyrażają ideę,

50 W omawianych tekstach P rdzeń בדל wystapił jedenaście razy, a w całym Pięcioksięgu pojawia się jeszcze jedynie dziewięć razy. Ponad połowa wystąpień wiąże się ze stworzeniem i prawem o rozróżnianiu nieczystości rytualnej. 
że są ludem wydzielonym dla Boga, ludem świętym: „Bądźcie więc świętymi, bo Ja jestem święty!” (Kpł 11,45). Hebrajski przymiotnik קדש (,święty”) także wiąże się z czynnością oddzielania. Izrael, przez zachowywanie prawa pokarmowego, przez oddzielanie wszystkiego, co nie mieści się w perspektywie Bożej, sam staje się ludem wydzielonym dla JHWH, ludem świętym. Ważnym spostrzeżeniem w teorii Douglas była jej wszechstronna definicja granicy. ${ }^{51}$ Badaczka pisała o Izraelitach: „Oto lud, który woli by nikt nie naruszał jego granic, każdą próbę ich przekroczenia uważając za wrogi atak. Nie spodziewa się żadnych korzyści z zewnętrznej wymiany i nie posiada zasad, które by ją ułatwiały". ${ }^{2}$ Prawa pokarmowe służyły wydzieleniu Izraela spośród jego sąsiadów. Idea separacji była wewnętrznie sprzężona z wyborem Izraela jako ludu świętego.

Stwórcze delimitacje przekraczają także mieszańce wśród zwierząt, jak wyżej wspomniany muł. W prawie pokarmowym zakazane są wszelkie zwierzęce hybrydy i krzyżówki. Łamaniem granic są także małżeństwa mieszane - obcy mąż czy żona prowadzą do religijnego i politycznego odstępstwa ${ }^{53}$ - oraz stosunki homoseksualne, mieszanie ról mężczyzny i kobiety. Zoofilia to też łamanie granic: „Nie będziesz obcował cieleśnie z żadnym zwierzęciem; przez to stałbyś się nieczystym. Także i kobieta nie będzie stawać przed zwierzęciem, aby się z nim złączyć. To jest sromota!" (Kpł 18,23). Takie mieszanie było dla prawodawcy „obrzydliwością”. Podobne podłoże miało prawo o niemieszaniu tkanin czy zakaz obsiewania pola dwoma różnymi rodzajami ziarna: „Nie będziesz łączył dwóch gatunków bydląt. Nie będziesz obsiewał pola dwoma rodzajami ziarna. Nie będziesz nosił ubrania utkanego z dwóch rodzajów nici" (Kpł 19,19); „Nie zasiejesz w twojej winnicy dwu gatunków roślin, aby wszystkie nie zostały uznane za święte: nasiona posiane i zbiory w winnicy. Nie będziesz orał razem wołem i osłem. Nie wdziejesz sukni utkanej naraz z wełny i lnu" (Pwt 22,9-11). Czyste jest za to to

${ }_{51}$ Zob. M. D o u g l a s, Ukryte znaczenia, s. 269nn.; o granicy także s. 391n.

52 Tamże, s. 392.

53 Tamíe, s. 270n. 
wszystko, co zachowuje granice, stwórcze limity narzucone przez Boga. Regulacjami kapłańskimi rządzą czasowniki בדל (,rozdzielać”) i קדש (,uświęcać”) - oba reprezentatywne zarówno dla Rdz 1, jak i dla Kpł 11. Gdy ludzie rozdzielają zwierzęta czyste od nieczystych, Izraelitów od pogan i szabat od innych dni tygodnia - uczestniczą w kreacyjnej aktywności Boga. W judaizmie na zakończenie szabatu dokonuje się ceremonii Hawdali (הבדלה - ,rozdzielenie”), czyli rytu oddzielenia czasu świętego od dnia powszedniego. Jej centralna modlitwa brzmi: „Błogosławiony jesteś Ty, HaSzem, nasz Bóg, Król Świata, który oddzielasz święte od powszedniego, światło od ciemności, Izraela od narodów, dzień siódmy od sześciu dni pracy. Błogosławiony jesteś Ty, HaSzem, czyniący rozróżnienie pomiędzy świętym a powszednim" (tzw. błogosławieństwo HaMawdil). Granica jest tu czymś więcej niż negatywną barierą wykluczenia. Ona chroni relację. Strzeże obszaru, wewnątrz którego działają zasady porządkujące rzeczywistość.

\section{Pozostałe podobieństwa i analogie Kpł 11 i Rdz 1}

Poza wskazanymi kategoriami stwórczymi łączącymi oba analizowane teksty, istnieje wiele innych cech prawodawstwa Kpł 11, które odsyła do Rdz 1 i skłania do interpretacji przepisów pokarmowych w kontekście teologii stworzenia. Wskażę najważniejsze łączące idee i wyrażenia.

I. Główną ideą stworzenia jest życie. W Rdz 1 jest ono stwarzane, a potem zachowywane, m.in. przez nakaz diety wegetariańskiej, nie odbierającej życia. Smierć nie jest tu obecna, nie ma potrzeby rozlewania krwi. Następnie to życie ma być przekazywane, pomnażane w akcie prokreacji tak ludzi, jak i zwierząt: „Bądźcie płodni i rozmnażajcie się” (Rdz 1,22.29). Ta naczelna idea stworzenia - idea świętości życia - odbija się jak w lustrze w prawie o nieczystości śmierci (Lb 19; Kpł 21) oraz nieczystości zwierząt, które odbierają życie, są drapieżnikami. Jedzenie służy podtrzymaniu życia tak samo jak prokreacja - jest więc istotnym elementem teologii życia. 
II. Bóg dostarcza ludziom pożywienie - to kolejna idea łącząca oba teksty. Nawet, jeśli dieta się zmienia, zasada pozostaje ta sama: to Bóg ustala, co wolno, a czego nie wolno jeść. JHWH wskazuje, co jest dobre i co należy spożywać. Nie jest przypadkiem, że przykazania o odżywianiu się padają właśnie w kontekście teologii kreacyjnej: w tekstach o stworzeniu świata, o potopie i o prawie pokarmowym. Wiemy już, że potop jest koncepcyjnie powiązany z opowiadaniem o stworzeniu, stanowi odnowienie stworzenia i ponowienie kreacyjnego działania Boga. Tam pojawia się pierwsza wzmianka o zwierzętach czystych i nieczystych (Rdz 7,2-3), która będzie rozwijana w Kpł 11. Te trzy kluczowe teksty i kluczowe przykazania nt. odżywania się - Rdz 1,29-30, Rdz 9,3-4 i Kpł 11 łączy nie tylko temat pokarmu, ale temat Bożego stworzenia. Są to kluczowe dla Starego Testamentu teksty o nakazanej przez Niebo diecie. Wszystkie wskazują na zależność człowieka od Boga, który jest dawcą życia i regulatorem sposobu odżywiania się. O ile pierwszy z nich jest bardzo restrykcyjny, nakazuje bowiem dietę jarską, a drugi bardzo permisywny, pozwala bowiem jeść wszystko do woli - trzeci jest jakąś formą pośrednią i wyważoną. Stawia bowiem ograniczenia, ale redukuje je do określonych sytuacji. Można obrazowo powiedzieć, że humanitarne prawo pokarmowe ustanawia rozejm między człowiekiem a zwierzęciem, łagodząc konflikt wywołany po potopie.

III. Bóg czyni człowieka na swój obraz i podobieństwo: „Uczyńmy człowieka a Nasz obraz, podobnego Nam (...). Stworzył więc Bóg człowieka na swój obraz, na obraz Boży go stworzył" (Rdz 1,26n.). Autor kapłański trzykrotnie podkreśla ten ważny dla niego fakt teologiczny (w Rdz 1, Rdz 5 i Rdz 9). Jest to dobrze znana, choć najczęściej błędnie interpretowana, idea imago dei - bycia obrazem Boga, o której szerzej pisałem gdzie indziej. ${ }^{54}$ Ta sama koncepcja naśladowania i bycia

54 M. M aj e w s k i, Pięcioksiag odczytany na nowo, s. 121-132. 
obrazem jest wyrażona w podsumowaniu prawa pokarmowego: „Bądźcie świętymi, ponieważ Ja jestem święty!” Autor kapłański powtarza to sformułowanie w Kpł 11,44 i 11,45, wyrażając ideę dążenia do bycia na obraz Boga i czynienia świata na wzór niebiańskiego modelu.

IV. Bóg w Rdz 1 daje człowiekowi władzę nad stworzeniem, zwłaszcza nad żywymi stworzeniami: ,...abyście panowali nad rybami morskimi, nad ptactwem powietrznym i nad wszystkimi zwierzętami pełzającymi po ziemi” $(1,28)$. Po potopie Bóg ponownie oddaje zwierzęta pod władzę człowieka: „Wszelkie zaś zwierzę na ziemi i wszelkie ptactwo powietrzne niechaj się was boi i lęka. Wszystko, co się porusza na ziemi i wszystkie ryby morskie zostały oddane wam we władanie" (Rdz 9,2). Władanie to umożliwia także spożywanie mięsa zwierząt, choć pod pewnymi warunkami (Rdz 9,3-4). To władanie zostaje potwierdzone w Kpł 11, gdzie Bóg określa, które gatunki i jak mogą być zabijane i spożywane. Wszystkie trzy teksty określają władzę człowieka nad żywymi stworzeniami, jednocześnie ustalając zakres tej władzy. Panowanie nad zwierzętami w kontekście Kpł 11 oznacza odpowiedzialne zarządzanie królestwem zwierząt, nawet jeśli człowiek otrzymał pozwolenie na zabijanie niektórych z nich na pokarm.

V. Dla obu porównywanych tekstów charakterystyczne jest słowo מין ,rodzaj”, ,gatunek”, pojawiające się w identycznym wyrażeniu ,według swego gatunku/rodzaju”: למינהו, למינון (למינה למינה lub zależności od rodzaju i liczby podmiotu). To wyrażenie pojawia się aż dziesięć razy w Rdz 1 i aż dziewięć razy w Kpł 11. Co istotne, występuje ono niemal wyłącznie w Pięcioksięgu (30 na 31 użyć w Biblii), a takie jego nagromadzenie spotykamy tylko w tych dwóch tekstach. Jest jeszcze jedno miejsce, gdzie pojawia się ponadprzeciętnie często, jest to opowieść o potopie ( $R d z$ 6-7) z sześcioma wystąpieniami. Mamy zatem znów te same trzy biblijne miejsca połączone ideą stworzenia jakby przewodnią nicią. Teksty te podejmują stwórczą ideę ustalenia gatunków i rodzajów 
istot żyjących oraz nieprzekraczania granic ustalonych norm. Niedawno szczegółową analizę rzeczownika מין w poemacie o stworzeniu przeprowadził Richard Neville. ${ }^{55}$ Autor wydobył wszelkie niuanse związane z występowaniem (bądź nie) tego rzeczownika w poszczególnych dniach stwarzania i formami, jakie tam przybiera. Dostrzegł także znaczące pokrewieństwo w użyciu tych formuł z kapłańskim opowiadaniem o potopie (Rdz 6-9) i przepisami pokarmowymi (Kpł 11). W konkluzji badacz stwierdził, że formuła למינ nie służy pokazaniu j a k Bóg stwarza (gatunek po gatunku), ale c o Bóg stwarza (wszystkie gatunki); nie mówi, ja k zwierzęta weszły do arki, ale kt ó re zwierzęta weszły do arki; i nie wskazuje, j a k zwierzęta nieczyste mają być unikane, ale k tó r y c h zwierząt należy się brzydzić. ${ }^{56}$

VI. Kolejna idea wspólna w Rdz 1 i Kpł 11 to uniwersalne postrzeganie świata i zasad w nim panujących, wyrażone za pomocą słowa כל (,wszystko”, „całość”, „każdy”). Słowo to jest użyte w Kpł 11 aż 36 razy, co świadczy o powszechnym i uniwersalnym zasięgu myśli autora nt. świata zwierząt, postrzeganiu go holistycznie i wyczerpująco. To powrót do idei z Rdz 1, gdzie to słowo pojawia się równie często - aż 29 razy - również wskazując uniwersalny zasięg myśli autora.

VII. Generalnie świat użytych pojęć bardzo oba opowiadania. Takich wspólnie występujących terminów znajdziemy więcej: ארץ w Kł 11 użyte jest osiem razy, a w Rdz 1 dwadzieścia dwa razy; מים użyto w Kpł 11 dziesięć razy, a w Rdz 1 jedenaście; użyto odpowiednio pięć i trzy razy; עוף użyto odpowiednio pięć i sześć razy; חיה użyto po cztery razy w obu tekstach. Eilberg-Schwartz zauważył, że zastosowanie dwóch różnych nazw dla zwierząt w Kpł 11,2 (בהמה i חיה) jest naśladowaniem

55 R. N e vi 11 e, Differentiation in Genesis 1. An Exegetical Creation ex nihilo, Journal of Biblical Literature 130/2011, s. 209-226.

56 Tamże, s. 226. 
poematu o stworzeniu z Rdz 1,24. ${ }^{57}$ Także inne kluczowe dla dzieła stwórczego pojęcia pojawiają się w obu tekstach. Jest to kolejna mocna przesłanka wskazująca, że światy Rdz 1 i Kpł 11 przenikają się wzajemnie bardziej, niż się na pierwszy rzut oka wydaje.

VIII. Wreszcie, idea kończąca oba teksty to idea świętości. W Rdz 2,3 czytamy, że Bóg „uświęcił czy uczynił świętym” (rdzeń קדש) dzień siódmy, dzień szabatu, a w Kpł 11,44-55 znajdujemy potrójne wezwanie do świętości (rdzeń קדש): „Ponieważ Ja jestem Pan, Bóg wasz - uświęćcie się! Bądźcie świętymi, ponieważ Ja jestem święty!... Bądźcie więc świętymi, bo Ja jestem święty!" Idea świętości silnie związana jest z ideą naśladowania Boga, imitatio dei, o której pisałem wyżej, oraz z ideą stworzenia. Świat stworzony zostaje wypełniony świętą obecnością Boga. Również życie ludzkie ma być tą świętością napełnione, bo stworzenie to postawienie człowieka w relacji do Boga, relacji do Świętego. Idea kryjąca się w pojęciu קדש to specyficznie biblijna idea, która nie tyle związana jest z moralnością i heroicznością cnót, ale z samym Bogiem. W Biblii to Bóg jest święty i to po trzykroć (Iz 6,3). Nie ma innego źródła świętości poza Nim. Bóg emanuje świętością tak silnie, że wszystko, co jest z Nim bezpośrednio związane - jak świątynia, ołtarz, ofiara, kapłan, prorok itp. - również zyskuje miano świętości: nie w sensie etycznym, ale w sensie odseparowania, odcięcia od świata profanum (związek z ideą בדל) i przeznaczenia wyłącznie dla Boga. W idei świętości zawiera się idea porządku, niemieszania wyznaczonych w stworzeniu granic, kompletności oraz braku wad. Ta sama idea odgrywa ważną rolę w prawie

57 H. E i l b e r g - S c h w a r t z, Creation and Classification in Judaism: From Priestly to Rabbinic Conceptions, s. 360-361. Kpł 11,2 sugeruje, że nie są to synoחהמה חיה (,istoty żyjące”) zawiera w sobie określenie lecz określenie ogólne (,zwierzęta jadalne”). Podobnie w Rdz 1,24 określenie חיה zawiera w sobie określenie בהמה , które oznacza bydło lub inne zwierzęta lądowe; zob. szerzej G.J. W e n h a m, Genesis 1-15, Word Biblical Commentary 1A, Thomas Nelson, Nashville 1987, s. 25. 
pokarmowym. Przestrzeganie regulacji co do diety jest zatem stwórczym rozróżnianiem, czynieniem tak, jak Bóg czyni; jest wprowadzaniem do świata idei świętości oraz samemu stawaniem się ,świętym, jak Bóg jest święty”.

Ta intertekstualna analiza utworów Rdz 1 i Kpł 11 ujawnia znaczące powiązania ideologiczne i leksykalne między regułami stworzenia i regułami odżywiania się. Związek między obu opowiadaniami bazuje na wspólnych ramach koncepcyjnych i tej samej strukturze postrzegania świata, ale nie ogranicza się tylko do tego. Prawo pokarmowe właśnie w kontekście reguł kreacji zyskuje nowe i całościowe uzasadnienie, którego poszukiwali badacze. Na podstawie powyższej analizy i szerszego spojrzenia na literaturę kapłańską oraz teksty prawne Tory wydaje się uzasadnione postrzeganie prawa pokarmowego przez pryzmat mitu stwórczego i interpretacja Kpł 11 $\mathrm{z}$ tej perspektywy.

\section{Cel prawa pokarmowego: świętość i oddzielenie ludu}

Wiele praw z Księgi Kapłańskiej ma uroczyste zakończenie. Wielokrotnie pojawia się np. formuła: „To jest prawo o...” (זאת התורה ל...), np. w Kpł 7,37; 12,7; 13,59; 14,32; 14,54-57; 15,32. Takie zakończenie pojawia się też w Kpł 11,46: „To jest prawo dotyczące zwierząt, ptaków i wszelkich istot żyjących, które poruszają się w wodzie, i wszelkich stworzeń pełzających po ziemi”. Przed nim jest podsumowanie prawa pokarmowego: „Ponieważ Ja jestem Pan, Bóg wasz - uświęćcie się! Bądźcie świętymi, ponieważ Ja jestem święty! Nie będziecie się plugawić małymi zwierzętami, które pełzają po ziemi. Bo Ja jestem Pan, który wyprowadził was z ziemi egipskiej, abym był waszym Bogiem. Bądźcie więc świętymi, bo Ja jestem święty!" (Kpł 11,44-45). W tych dwóch wersetach na czoło wyraźnie wysuwa się kategoria świętości. Celem prawa pokarmowego w Kpł 11 jest osiągnięcie świętości (rozumianej biblijnie). Świętość człowieka to ostateczne wyjaśnienie prawa pokarmowego. O ile kategorie stwórcze są źródłem prawodawstwa, podstawą wyodrębnienia zwierząt nieczystych (niezgodnych z porządkiem stworzenia) i wyeliminowanie ich z diety, 
o tyle świętość jest jego celem. Kategorie stwórcze ładu i rozróżniania pojawiają się na początku, zaś kategoria świętości na końcu prawa pokarmowego. „Bycie świętym” w kontekście prawa pokarmowego to bycie oddzielonym, ale nie tyle o d czegoś (grzechu, pogan, nieczystości itd.), ile raczej d o służby Bożej. „Bycie świętym” oznacza zachowywanie ustalonych przez Boga granice i respektowanie stworzonego porządku. Człowiek jest wezwany do świętości na podobieństwo Boga, a więc do rozróżniania, do oddzielania czystego od nieczystego, a z drugiej do udziału w wyjątkowości Boga, który jest święty. Textus classicus idei świętego ludu jest Wj 19,6 (P): „Wy będziecie Mi królestwem kapłanów i ludem świętym”. Izraelita, który na co dzień styka się z nieczystością, musi się oczyścić i dbać o brak skazy. Inaczej nie zbliży do sanktuarium, do świętego Boga. Nieczystość bowiem wyklucza go z udziału w kulcie.

Wersety Kpł 11,44n. łączą przyczyny podziału zwierząt z tematem świętości Izraela i wyzwolenia z niewoli egipskiej. W Pwt 14,2, wersecie poprzedzającym przepisy pokarmowe, jest podobnie: ,...bo wy jesteście ludem poświęconym Panu, Bogu swemu: was wybrał Pan, byście się stali ludem będącym Jego wyłączną własnością spośród wszystkich narodów, które są na ziemi”. Każdy posiłek przypominał Izraelitom, że Bóg ich wybawił z Egiptu i uczynił ich narodem świętym. Bóg okazał stwórczą moc w wyprowadzeniu Izraela przez wody Morza Sitowia, które rozdzielił, jak rozdzielił wody w stworzeniu.

Jednym z jasno wyrażonych celów praw o czystości było oddzielenie Izraela od innych narodów (גויים). Izraelici przestrzegali nakazanej diety nie dlatego, że jest zdrowa, higieniczna czy nie budząca wstrętu (zob. hipotezy omówione w poprzednim artykule). Kultywowali i kultywują prawo pokarmowe dlatego, że stało się elementem tożsamości ludu JHWH, wyznacznikiem przynależności religijno-narodowej, ważnym elementem samorozumienia. W zachowywaniu tego prawa Izrael potwierdza, że jest wybrańcem Boga. Taka dieta również zniechęca do braterstwa stołu z sąsiadami, np. Kananejczykami, którzy spożywali wieprzowinę i inne składniki uznawane w Izraelu za nieczyste. Te przepisy więc były praktycznym środkiem utrzymania Izraela jako ludu świętego. Ten związek między przestrzeganiem 
prawa pokarmowego i świętością Izraela - oddzieleniem od innych narodów wprost wyrażony jest w Kpł 20,25-26: „Będziecie odróżniać zwierzęta czyste od nieczystych, ptaki nieczyste od czystych. Nie będziecie plugawić siebie samych przez zwierzęta i ptaki ani przez wszystko, co się roi po ziemi, przez wszystko, co oddzieliłem od was jako nieczyste. Będziecie dla Mnie święci, bo Ja jestem święty, Ja Pan, i oddzieliłem was od innych narodów, abyście byli moimi”. Douglas twierdzi, że system klasyfikacji zwierząt odzwierciedla ogólniejszy wzorzec, system społeczny. Kategoryzacja zwierząt to na wyższym poziomie wyznaczenie linii demarkacyjnej pozwalającej odróżnić od siebie dwie klasy ludzi: Izraelitów i resztę. ${ }^{58}$ Prawa koszerności pozwalały na utrzymanie oddzielności i odrębności. Tworzyły rodzaj własnej samoświadomości, poczucia wspólnoty i odrębności. Kryje się za tym idea przynależności do JHWH, odseparowania od innych narodów - przez inne od wszystkich zachowanie i przepisy. Bóg oddzielił ich od innych narodów. Bóg także ciągle działa przez rozdzielanie, oddzielanie. Dieta okazuje się znakomitym środkiem do oddzielenia Izraela, oznaczenia go jako narodu świętego, budowania i strzeżenia jego świętości. Odrębna dieta miała być codziennym przypomnieniem dla Izraelitów, że są odrębnym organizmem.

W tym kontekście dodatkowego teologicznego znaczenia nabiera porzucenie tych praw w Nowym Testamencie i wspólnocie pierwszego Kościoła - której celem było przecież otwarcie się na wszystkie narody. Jeśli zachowywanie prawa o czystości tworzyło barierę między Żydami a narodami, to porzucenie tych praw symbolizowało przełamanie tej granicy, bariery oddzielającej. ${ }^{59}$ Wezwanie do świętości pozostaje, ale nie ma już charakteru etnicznego. Katolicki post piątkowy to chyba jedyny rytuał, którzy przenosi symbole i prawdy chrześcijańskie do „kuchni”, na sposób żydowskich reguł nieczystości

58 M. D o u g l a s, Ukryte znaczenia, s. 370.

59 G. Wenham, Christ's Healing Ministry and His Attitude to the Law, w: H.H. R ow d o n (red.), Christ the Lord. Studies in Christology presented to Donald Guthrie, Biblical Studies, Cambridge 1982, s. 122; J. M i 1 g r o m, Leviticus 1-16, s. 726. 
pokarmowych - jak dzień, czas symboliczny (choć współcześnie w warstwie intelektualnej nastąpiło przesunięcie tego gestu z wymiaru symbolicznego na wymiar etyczny, widać to zwłaszcza tam, gdzie ten post zniesiono i zastąpiono jałmużną). Podobnie jak żydowskie prawo pokarmowe stanowi on wyznacznik wierzącego podobnie wyznacza silne społeczne granice. Tak jak ortodoksyjny Żyd nie zje wszystkiego na publicznej uczcie, tak katolik nie zje wszystkiego w piątek. Obie reguły wyznaczają granice. Granice ludu bądź granice konfesji. Stanowią o swoistości, odrębności. Charakter społeczny posiłku jest dziś w antropologii czymś oczywistym. ${ }^{60}$ Tak, jak człowiek oddziela siebie od natury, od zwierząt i świata, tak pojęcie świętości oddziela świat Boga od człowieka. Nieczystość oddziela. Jest to znana teza Durkheima, że właściwości systemu klasyfikacji są pochodną systemu społecznego, którym się posługuje, $\mathrm{i} w$ istocie jego właściwościami. Autor biblijny posługuje się zwierzętami, by ukazać miejsce Izraela we wszechświecie należącym do Boga. Izrael w tym układzie jest symbolizowany przez zwierzęta czyste lądowe, gdyż tylko Izraelici byli odseparowani do reszty świata, jak ich uświęcone stada i trzody zwierząt nadających się do stołu i ołtarza.

\section{Stworzenie jako kryterium}

Nie tylko zasady prawa pokarmowego, ale w ogóle zasady życia codziennego, obyczaju, higieny, seksu, etyki, a zwłaszcza zasady życia kultowego są pochodną niejawnych założeń na temat sposobu funkcjonowania świata. Zasady higieny są racjonalnie powiązane z budową kosmosu. Poemat o stworzeniu $(\operatorname{Rdz} 1,1-2,4)$ zapewnia model koncepcyjny, aby zrozumieć wszechświat, stanowi schemat poznawczy, w którym rzeczywistość jest dokładnie określona i zdefiniowana. Wszystko, co narusza klasyfikację, która jest zdefiniowana w tej historii stwórczej, jest traktowane jako błąd w stworzeniu i dlatego jest nienormalne i nieczyste. Posiłek, po odszyfrowaniu, okazuje

${ }_{60}$ M. D o u g l a s, Symbole naturalne. Rozważania o kosmologii, tłum. E. D ż u r a k, Wydawnictwo Uniwersytetu Jagiellońskiego, Kraków 2004, s. 83. 
się streszczać religię. To, co dostaje się do wnętrza ciała i je tworzy, nie może łamać kategorii kulturowych i praw religijnych.

W Rdz 1 Bóg rozdzielił przestrzenie, ustanowił granice i normy, ustalił ład i porządek, dał zwierzętom trawę na pożywienie, także zwierzętom drapieżnym. Zakazy żywnościowe w Kpł 11 starają się budować na tych zasadach. Wyraźną intencją prawodawcy jest wykluczenie z diety Izraela wszystkich zwierząt, które żywią się mięsem z krwią (mówiliśmy o szczególnym przypadku ryb). Nigdzie w Biblii nie ma zgody na to, by zwierzęta jadły krew. Dieta jarska ustalona w raju przenosi się na wegetariańskie zachowanie zwierząt czystych i na prawo pokarmowe. Co prawda także niektóre roślinożerne zwierzęta zostały wkluczone, ale ich tabuizacja opiera się na innych podstawach stwórczych. Tu mieści się teoria Milgroma, który twierdził, że głównym celem prawa pokarmowego było zachowanie życia, nauczenie szacunku wobec świętości życia. Choć, jak wykazywałem, nie jest to wystarczające i jednoznaczne kryterium, to jak najbardziej mieści w ramach porządku stwórczego, gdzie Bóg okazuje się Stwórcą, Panem i Obrońcą życia, a raj jest królestwem życia.

Wszelkie tłumaczenia naturalne prawa pokarmowego nie będą na tyle adekwatne i całościowe, by właściwie ująć i zinterpretować cały system. Jedynie szeroko rozumiana teologia stworzenia potrafi zadowalająco objąć to prawo jako całość. Prawodawca zdawał sobie sprawę, że nie można tak ważnych reguł prawnych układać ot tak sobie, że trzeba je oprzeć na solidnym wzorcu, najlepiej na najistotniejszym fundamencie - czyli na niewzruszonych podstawach zapewnionych przez Stwórcę. Reguły prawa mają naśladować intencje i wzorce, według których świat został stworzony. Ponieważ nie było w nim miejsca dla zwierząt mięsożernych i nieharmonijnych, zostały one wykluczone $\mathrm{z}$ diety Bożej i ludzkiej. Zauważalna jest tu analogia z szabatem, tak ważną instytucją judaizmu. Czy Biblia podaje racjonalne uzasadnienie szabatu? Nie. Podaje za to w wielu miejscach inne, bardziej fundamentalne uzasadnienie jego przestrzegania. Wynika ono z tekstu Rdz 1, stwórczej działalności Boga, gdyż nawet Bóg musiał odpocząć. Podstawowe uzasadnienie dla tej 
instytucji to - jak w przypadku prawa pokarmowego - odniesienie do mitu kreacyjnego.

Kategorie stwórcze zastosowane do podziału zwierząt to przede wszystkim niemięsożerność, potem rozłączność (zachowywanie ustalonych granic i norm własnego środowiska) i ponadto integralność (pełna skończona postać anatomiczna, właściwe pełne i skończone narządy). Zauważmy, że także człowiek, jeśli jest przeznaczony do kultu - jako kapłan - także musi tę cechę integralności spełniać: „Ktokolwiek z potomków twoich według ich przyszłych pokoleń będzie miał jakąś skazę, nie będzie mógł się zbliżyć, aby ofiarować pokarm swego Boga. Żaden człowiek, który ma skazę, nie może się zbliżać - ani niewidomy, ani chromy, ani mający zniekształconą twarz, ani kaleka, ani ten, który ma złamaną nogę albo rękę, ani garbaty, ani niedorozwinięty, ani ten, kto ma bielmo na oku, ani chory na świerzb, ani okryty liszajami, ani ten, kto ma zgniecione jądra. Żaden z potomków kapłana Aarona, mający jakąś skazę, nie będzie się zbliżał, aby złożyć spalaną ofiarę Panu. On ma skazę - nie będzie się zbliżał, aby ofiarować pokarm swego Boga" (Kpł 21,17-21). Integralne powinno być także zwierzę ofiarne: „Nie będziecie składać w ofierze Panu zwierząt ślepych, ułomnych, okaleczonych, spuchniętych, parszywych, owrzodzonych. Nie będziecie takich zwierząt składać na ołtarzu na ofiarę spalaną dla Pana. Cielca albo barana niekształtnego lub niewyrośniętego możesz złożyć jako ofiarę dobrowolną, ale jako ofiara ślubowana nie będzie on przyjęty" (Kpł 22,22-23). Kategorie stwórcze to bowiem - w moim przekonaniu klucz do zrozumienia nie tylko prawa pokarmowego, ale całego prawodawstwa kapłańskiego Pięcioksięgu.

Pomocne, choć znacznie szerzej zakrojone badania antropologiczno-egzegetyczne nad zjawiskiem tabu, m.in. biblijnych tabu, opublikował niedawno Jerzy Wasilewski. ${ }^{61}$ Autor zauważa, że system zakazów magiczno-rytualnych Biblii „służy stworzeniu (odtworzeniu) w planie symbolicznym idealnej, pożądanej sytuacji, przede wszystkim zaczątkowej; będzie ona modelowana na wzór

61 J. W a s i le w s k i, Tabu. 
mitycznej sytuacji początkowej (nieskalanej, rajskiej), w której nie istniały nieczystość i inne skażenia". ${ }^{62}$ Dalej Wasilewski pisze: „Zakazy zapewniają usunięcie skalania, którego nie było przecież w mitycznej epoce nieskażonych początków (...). Zakaz magiczny pomaga $\mathrm{w}$ sformułowani idealnego początku w ten sposób, że - przez eliminację wykroczeń - odtwarza wzorcową sytuację takich właśnie początków, opisaną w mitach i wyobrażeniach na temat raju". ${ }^{63}$ Tabu nieczystości biblijnej ma na celu stworzenie maksymalnie najlepszych warunków początkowych, wzorowanych na rajskich początkach. Z kolei wykroczenia przeciw zakazom powodują skutki negatywne wzorowane na konsekwencjach mitycznego upadku, utraty raju. Patrząc jeszcze szerzej na tę koncepcję, należy przywołać także badania czołowego religioznawcy i historyka religii XX w., Mircei Eliadego, z jego kluczową obserwacją, że działania religijne i rytualne to realizacja świata idealnego, mitycznego świata początkowego. Eliade dowodził, że archetypów religijnych nie da się w pełni pojąć bez właściwego im mito-rytualnego powrotu do idealnych początków, do „modelowego wzorca” - wzorca, który objawia się w micie, a aktualizuje w rytuale. ${ }^{64}$

\section{$* * *$}

Znaczenie podziału na to, co czyste i nieczyste, ujawnia się dopiero wówczas, gdy mamy do czynienia z pełną klasyfikacją wszechświata, gdy system jest widziany w swej totalności. Napisałem we wstępie, że sytuacja spożywania posiłku zawsze niesie ciężar struktury symbolicznej, innej dla każdej religii czy kultury. A „symbol posiada znaczenie tylko w relacji do innych symboli we wzorcu. Wzorzec nadaje mu znaczenie. Stąd żaden pojedynczy, izolowany od innych

62 Tamże, s. 27.

63 Tamże, s. 28.

${ }^{64}$ Zob. np. M. E 1 i a de, Sacrum i profanum. O istocie religijności, tłum. R. R e s z k e, Wydawnictwo KR, Warszawa $1999^{2}$ czy t e n ż e, Aspekty mitu, tłum. P. M ró w c z y ń s k i, Wydawnictwo KR, Warszawa 1998. 
element wzorca nie może być nośnikiem znaczenia". ${ }^{65}$ Dlatego trzeba rozpatrywać prawo pokarmowe w kontekście szeroko ujętej teologii źródła P. Mary Douglas w przedmowie do swej książki z 1999 r. napisała: „Nie ma sensu poszukiwać znaczenia pojedynczego symbolu, ani przyglądać się pojedynczym znaczeniom z nadzieją, że uda się znaleźć coś, co da się przełożyć na nasz język. Znaczenie jest częścią świata, który został skonstruowany, a problem rozumienia symboli polega na znalezieniu sposobu, by uchwycić cały ten świat". ${ }^{66} \mathrm{Nie}$ znajdziemy odpowiedzi na pytanie o sens prawa pokarmowego Biblii jedynie w kontekście innych praw o nieczystości, czy nawet w kontekście innych praw pokarmowych Biblii, jak prawo Noachickie czy zakaz spożywania krwi. Trzeba spojrzeć na nie jako na część świata wykreowanego przez kapłańskiego prawodawcę Tory i szukać sposobu, by uchwycić cały ten świat.

Historia poszukiwań i interpretacji prawa pokarmowego Tory wskazuje, że nie ma pojedynczego i łatwo uchwytnego kryterium uwzględniającego wszystkie przypadki. Prawem tym rządzi system, złożona idea, którą ująć można jako ład stworzenia, zasady stwórcze. Wiele ważnych czynników tworzy cześć tego systemu, a ona sama jest ideą przewodnią. Pojedynczy czynnik nie jest w stanie wyjaśnić wielu niuansów i złożoności tego ustawodawstwa, ale cały system porządku kreacyjnego już tak. W poprzedniej części zwróciłem uwagę na to, że cechą wspólną różnych rozwiązań i interpretacji prawa pokarmowego jest skupianie się na zwierzętach wykluczonych z jadłospisu, na tych, które odstają od normy, są tabu - jak np. świnia czy wielbłąd. To one przykuwają uwagę badaczy i to objaśnienie ich anomalności zajmuje gros miejsca w ich pracach. W mojej propozycji jest inaczej. Uważam, że wykluczenia są tylko produktem ubocznym, pochodną określonej wizji świata i to ta wizja, a w niej zwierzęta czyste powinny znaleźć się w centrum rozważań. Wiele z interpretacji prawa pokarmowego Biblii robi wrażenie przygotowania ich ad hoc, doraźnie, na potrzeby komentarza do danej perykopy czy zjawiska

${ }_{65}$ M. D o u g 1 a s, Symbole naturalne, s. 33.

${ }^{66} \mathrm{~T}$ a ż, Ukryte znaczenia, s. 21. 
samego w sobie. Zwłaszcza w odbiorze potocznym widać tendencję do uproszczeń i wybiórczych etiologii. Tak się nie da wyjaśnić prawa pokarmowego Biblii. Kolejną słabością niektórych analiz jest to, że badacze prawa czystości skupiają się na dosyć wąskim kontekście, najczęściej prawach o czystości (Kpł 11-15).

Przy fundamentalnej różnicy między człowiekiem a zwierzęciem, jest też w źródle P wiele podobieństw między ludźmi i zwierzętami: jedni i drudzy są stworzeni i pobłogosławieni przez Boga do rozmnażania się i zaludniania ziemi, mają tę samą jarską dietę wegetariańską, mają krew i tchnienie życia, są więc istotami żyjącymi, grożą im te same kary za zabójstwo, wreszcie przestrzegać muszą tego samego nakazu szabatu. To oznacza, że dla Boga zwierzęta nie są tylko „mięsem”, ale że powinny być otaczane opieką i traktowane właściwie. Prawo pokarmowe to $\mathrm{w}$ istocie seria obostrzeń w dostępie człowieka do świata zwierząt. Człowiek ma nad nimi panować, ale to panowanie ma być na wzór panowania Boga. Ostatecznie przecież cały świat i jego mieszkańcy należą tylko do Niego (Ps 24,1).

Marcin MAJEWSKI

Słowa kluczowe: źródło kapłańskie; czyste; nieczyste; zwierzęta czyste i nieczyste; Rdz 1

Keywords: Priestly source; clean; unclean; clean and unclean animals; Genesis 1

\section{Clean and Unclean Animals in the Old Testament}

Summary

The article explicates the symbolic information in the biblical division of animals between clean and unclean (Lev 11 and Dt 14). This is the third article in the series. In the first article on the subject of unclean animals in the Bible, I dealt with the discussion of legislation in this field. In the 
second article I presented and analyzed the exegetes' previous interpretations regarding the division of animals in the Bible. Because they proved to be unsatisfactory to me, in this part I proposed my own hypothesis: the exclusion of unclean animals is regulated by the Priestly (P) theology of creation and the rules of the universe created by God contained in Gen 1. 